JOSÉ RICCI JÚNIOR

\title{
Polimorfismo do exon 20 do gene da elastina em indivíduos portadores de doença diverticular dos cólons
}

Tese apresentada à Faculdade de Medicina da Universidade de São Paulo para obtenção do título de Doutor em Ciências

Área de concentração: Clínica Cirúrgica Orientadora: Prof ${ }^{\mathrm{a}}$. $\mathrm{Dr}^{\mathrm{a}}$. Consuelo Junqueira Rodrigues 
“...E que realmente a vida tem valor

E que você tem valor diante da vida! Nossas dádivas são traidoras E nos fazem perder O bem que poderíamos conquistar Se não fosse o medo de tentar..."

William Shakespeare 
“nós vos pedimos com insistência, não digam nunca: isto é natural ! Diante dos acontecimentos de cada dia, numa época em que reina a confusão.

Em que corre sangue, em que o arbítrio tem força de lei. Em que a humanidade se desumaniza, não diga nunca : isto é natural ! Para que nada passe a ser imutável! “ 
DEDICATÓRIA 
Aos meus pais José e Aparecida e à tia Luzia Carolina Gallo a quem eu devo tudo o que sou, por todo amor, paciência, carinho e incentivo. 
À minha esposa Romana, companheira e amiga, sem cuja ajuda eu jamais teria conseguido concluir este trabalho. 
Aos meus filhos, Bruno, Vitor, Ana Luísa e José, "que este trabalho, fruto de grande esforço pessoal, sirva como referência para suas vidas e para lembrarem sempre que o maior patrimônio de uma pessoa é constituído pelo conhecimento somado aos vínculos de afeto que construímos durante nossa breve passagem pela vida, pois serão eles que determinarão o nosso legado para o mundo." 
AGRADECIMENTOS 
A Deus pelo dom da vida, pelas inúmeras graças a mim concedidas e principalmente pelos mais valiosos presentes que me deu: meus pais, meus filhos, minha mulher, meus irmãos Jane e Leandro, familiares e amigos;

Aos pacientes, sem a colaboração dos quais seria impossível executar este estudo;

À minha orientadora Prof ${ }^{\mathrm{a}}$. $\mathrm{Dr}^{\mathrm{a}}$. Consuelo Junqueira Rodrigues pela percepção, oportunidade, paciência e maturidade com que conduziu o processo de construção deste trabalho;

Ao Prof. Dr. Aldo Junqueira Rodrigues Júnior pela percepção, oportunidade e visão;

Ao Doutor Adérson Omar Mourão Cintra Damião pelo incentivo e preciosa ajuda na elaboração deste trabalho;

Ao Doutor José Guilherme Nogueira da Silva pela realização das colonoscopias nos pacientes do presente estudo;

À Doutora Karla Melo pelas importantes observações e ajuda;

Ao Prof. Doutor Ruy Geraldo Bevilacqua pelas valiosas sugestões e colaboração no tratamento estatístico dos resultados deste estudo; 
Aos funcionário(a)(s) Alexandre, André, Gina, Maria das Graças e Marilda do Laboratório de Anatomia Médico-Cirúrgica (LIM 02) da FMUSP, São Paulo, sem ajuda dos quais não teria sido possível a realização deste estudo;

Às funcionárias Leide, Mariliza e Shirley da Disciplina de Topografia Estrutural Humana da FMUSP - SP, pela amizade e carinho;

Ao idealista e lutador Jorge Curbelo e à Rogéria Cristina Dias pela grande dedicação, amizade e carinho;

À amiga Maria Laura Lacava Lordello pela ajuda;

À minha Professora do Jardim de Infância Maria de Lourdes Novaes Carvalho (in memoriam);

À minha alfabetizadora Professora Ivana Ceribelli Martelli;

Ao Professor Darcy Amâncio (in memoriam) representando os professores da escola estadual de $1^{\circ}$ e $2^{\circ}$ graus "Anísio José Moreira" da cidade de Mirassol, SP; 
Ao professor Lincoln Etchebehere Júnior representando os professores da escola estadual de $1^{\circ}$ e $2^{\circ}$ graus “José Felício Miziara" de São José do Rio Preto, SP;

Ao amigo-irmão Doutor José Eduardo de Nogueira Forni pelos anos de convivência e companherismo;

Aos Professores Doutores Carlos Solé-Vernin, José de Carvalho Sombra e Newton Antônio Bordin Júnior pela deferência de suas amizades e representando os professores da Faculdade Regional de Medicina de São José do Rio Preto, SP;

Aos amigos da XVI turma da Faculdade Regional de Medicina e do Hospital de Base de São José do Rio Preto, SP;

Ao Prof. Doutor Dioclécio Campos Júnior, Professor Titular da Disciplina de Pediatria da Universidade de Brasília, DF, atual Presidente da Sociedade Brasileira de Pediatria e sua esposa Eda pela amizade, carinho e referência;

Ao Prof. Doutor Dario Birolini, Prof. Titular da Disciplina de Cirurgia do Trauma da FMUSP - SP, São Paulo, e sua esposa Marilda pela amizade, carinho, confiança, ajuda e pelo que pudemos construir; 
Ao Prof. Doutor György Miklos Böhn pela visão futurista, percepção evolucionista e pelos relevantes serviços prestados à divulgação do ensino médico no Brasil;

À Doutora Regina Christina Wielenska pelas observações e amizade;

Aos Doutores Ricardo Tavares e Su Chao e ao Prof. Doutor Eduardo Luis Rachid Cançado, pela amizade e ajuda;

Ao meu Professor de Cirurgia, Doutor Celso de Oliveira Bernini e sua esposa Elizabete pela amizade, ajuda, dedicação, confiança e paciência;

Ao Doutor Cláudio Augusto Viana Birolini e ao Doutor Edivaldo Mitio Utiyama pela amizade, carinho, ajuda, confiança e ensinamentos cirúrgicos durante todo o tempo;

Às funcionárias Ângela, Deise e Rosângela, da Disciplina de Cirurgia do Trauma da FMUSP-SP, pela amizade e carinho;

À todos amigos e funcionários do Complexo Hospital das Clínicas da Faculdade de Medicina da Universidade de São Paulo, São Paulo e da Faculdade de Medicina da Universidade de São Paulo, São Paulo, SP;

Ao Sr. José Maria de Pereira Rio representando os amigos do Luzita; 
À todos aqueles que, direta ou indiretamente, estiveram envolvidos nesta pesquisa, possibilitando sua conclusão e cujos nomes involuntariamente não figuram nesta lista, meus agradecimentos. 
SUMÁRIO 


\title{
SUMÁRIO
}

\author{
Lista de figuras \\ Lista de siglas \\ Lista de tabelas e gráfico \\ Resumo
}

Summary

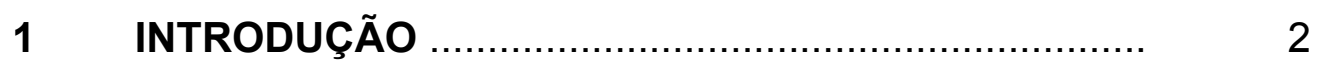

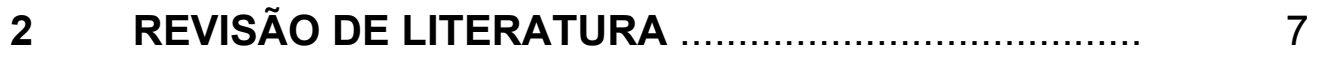

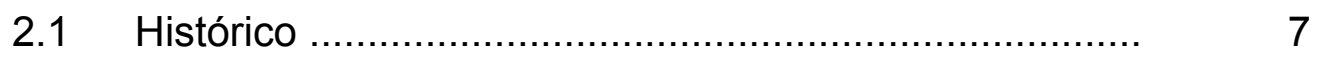

$2.2 \quad$ Etiopatogenia.............................................. 9

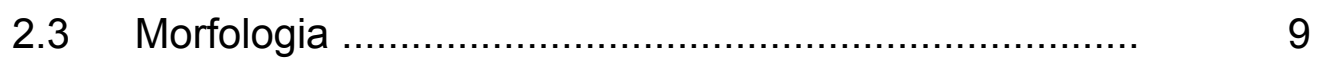

2.4 Estudos sobre a Atividade Motora do Cólon e Relação com as Fibras Vegetais ................................... 17

$2.5 \quad$ Sistema de Fibras Elásticas .................................. 20

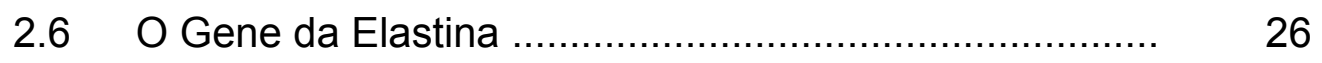

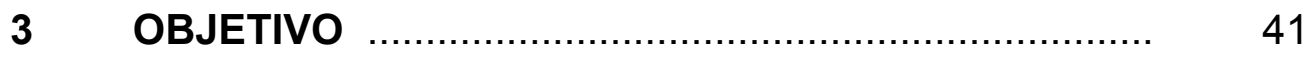

$4 \quad$ CASUÍSTICA E MÉTODOS .................................. 42

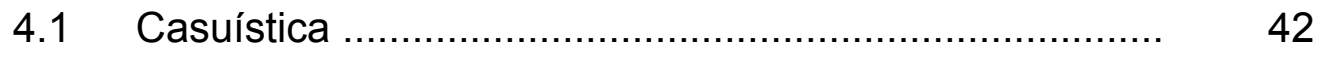

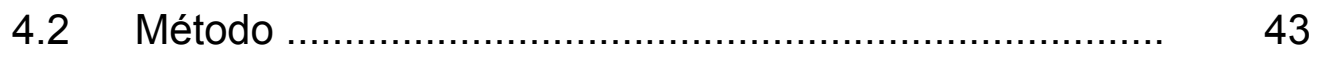

4.2.1 Extração do DNA genômico ................................... 43

4.2.2 Determinação por espectrofotometria ....................... 44

4.3 Amplificação do DNA ........................................ 45

4.4 Análise de polimorfismo por SSCP ....................... 47

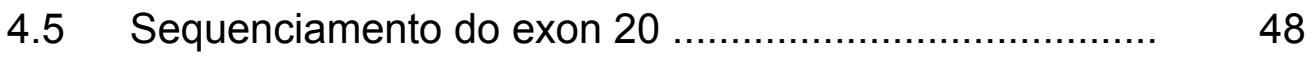


4.6 Análise estatística ..................................................... 48

$5 \quad$ RESULTADOS …................................................... 50

5.1 Grupos estudados: pacientes com DDC e controles ..... 50

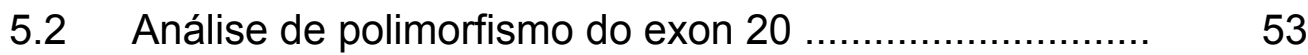

$5.2 \quad$ Analise de sequência do exon 20 ................................. 54

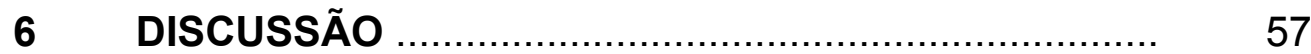

$7 \quad$ CONCLUSÕES .........................................................

8 REFERÊNCIAS BIBLIOGRÁFICAS …….................... 71 
LISTA DE SIGLAS 


\section{Lista de Siglas}

\begin{tabular}{ll} 
AGCC & - Ácido graxo de cadeia curta \\
AGT & - Adenina-Guanina_Timina \\
Ca. & - Califórnia \\
cDNA & - Ácido Dexorribonucleico complementar \\
CDD & - Colonic Diverticular Disease \\
dATP & - Oligo A \\
dCTP & - Oligo C \\
DDC & - Doença Diverticular do Cólon \\
dGTP & - Oligo G \\
DMSO & - Dimethylsulfoid \\
DNA & - Ácido Dexorribonucleico \\
DNTPs & - Conjunto dos oligos \\
dTTP & - Oligo T \\
EASV & - Estenose aórtica supravalvar \\
EDTA & - Ácido etilendiaminotetracético \\
ELN & - Elastina \\
FBLN5 & - Fibulina 5 \\
FBN & - Fibrilina \\
FBN1 & - Fibrilina1 \\
GGT & - Guanina-Guanina-Timina \\
GIBCO BRL & - Fabricante \\
HC-FMUSP & - Hospital das Clínicas da Faculdade de Medicina de \\
& da Universidade de São Paulo \\
\hline
\end{tabular}




\begin{tabular}{|c|c|}
\hline KHCO3 & - Bicarbonato de sódio \\
\hline kb & - Kilobases \\
\hline kda & - Kilodalton \\
\hline LIM 02 & - Laboratório de Investigação Médica 02 \\
\hline Milli Q & - Água pura ultrapura \\
\hline $\min$ & - Minutos \\
\hline MJ research & - Fabricante \\
\hline ml & - Mililitro \\
\hline $\mathrm{mg} / \mathrm{ml}$ & - Miligrama por mililitro \\
\hline M - MOL & - Milimol \\
\hline mRNA & - Ácido ribonucleico mensageiro \\
\hline $\mathrm{NaCl}$ & - Cloreto de sódio \\
\hline $\mathrm{NaCl} 6 \mathrm{M}$ & - Cloreto de Sódio com concentração de 6 molar \\
\hline $\mathrm{NH} 4 \mathrm{Cl}$ & - Cloreto de amônio \\
\hline $\mathrm{nm}$ & - Nanômetros \\
\hline nM & - Nanomolar \\
\hline \multirow[t]{2}{*}{ PCR } & - Polimerase Chain Reaction (Reação em Cadeia de \\
\hline & Polimerase) \\
\hline pH & - Potencial hidrogeniônico \\
\hline PTC - 100 & - Aparelho (MJ research) \\
\hline RNA & - Ácido ribonucleico \\
\hline rpm & - Rotações por minuto \\
\hline SDS & - Sódio dodecil sulfato \\
\hline SSCP & - Single Strand Conformation Polymorphism \\
\hline
\end{tabular}


- Síndrome de Williams

Taq

- Enzima

TCA

- Timina-Citosina-Adenina

TCC

- Timina-Citosina-Citosina

TE

- Conservante do DNA

TGF $\beta 1$

- Fator de crescimento beta 1

Tris-HCl

- Reagente

TTA

- Timina-Timina-Adenina

TTT

- Timina-Timina-Timina

V

- Voltagem

ul

- MICROLITROS

U.S.A.

- Estados Unidos da América 
LISTA DE FIGURAS 


\section{Lista de Figuras}

Figura $\quad 1$ - Esquema da deposição de elastina ....................... 21

Figura $\quad 2$ - Organização das fibras elásticas a nível molecular ........ 23

Figura $\quad 3$ - Cortes histológicos do cólon ................................. 25

Figura $\quad 4$ - Imagem tridimensional da elastina ....................... 32

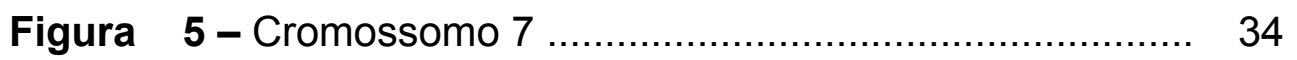

Figura 6 - Mapeamento do cromossomo 7 ........................... 35

Figura 7 - Polimorfismo conformacional de simples fita ......... 46

Figura 8 - Eletroforese de poliacrilamida …………………....... 53

Figura $\quad 9$ - Resultado do sequenciamento ............................ 54

Figura 10 - Diagrama tradicional da DDC …......................... 68

Figura 11 - Diagrama dos conceitos atuais e futuros da DDC .. 69 
LISTA DE TABELAS 


\section{Lista de Tabelas}

Tabela $\quad 1$ - Revisão histórica da DDC................................... 8

Tabela $\quad 2$ - Evolução histórica do conceito de DDC ............. 11

Tabela $\quad 3$ - Classificação da DDC por Ryan ......................... 14

Tabela $\quad 4$ - Evolução histórica da fisiopatologia da DDC ...... 16

Tabela $\quad \mathbf{5}$ - Estudos históricos de pressão intracolônica ........ 18

Tabela $\quad 6$ - Sumário dos estudos da pressão intracolônica .. 19

Tabela $\quad 7$ - Fibras elásticas, componentes e constituição .... 22

Tabela $\quad 8$ - Estudo dos casos controles ............................... 51

Tabela $\quad 9$ - Estudo dos pacientes com DDC ……................ 52

Tabela 10 - Análise Estatística Comparativa ........................ 55

Tabela 11 - Estatística pelo Teste Exato de Fisher .............. 56

Tabela $\quad 12$ - Risco Relativo ................................................ 56 
RESUMO 
RICCI Jr., J. Polimorfismo do exon 20 do gene da elastina em indivíduos portadores de doença diverticular dos cólons. São Paulo, 2004. 98p. Tese (Doutorado) - Faculdade de Medicina, Universidade de São Paulo.

A doença diverticular dos cólons (DDC) é relacionada à civilização, industrialização e à dieta. Estudos fisiológicos demonstraram que uma pressão intraluminal elevada, bem como alterações estruturais adquiridas da parede intestinal parecem ser fator decisivo, que se intensificam com 0 envelhecimento. Estas alterações podem ser causadas por alterações no tecido muscular e tecido conjuntivo relacionados ao metabolismo do colágeno e elastina, que presumivelmente pode ser geneticamente determinada. Sabe-se que pacientes com desordens genéticas do gene da elastina (ELN), como a estenose aórtica supravalvar e a cutis laxa, podem manifestar hérnia, diverticulose e disfunção urinária. Recentemente, foi demonstrado mutação pontual no exon 20 do ELN em pacientes com hérnia inguinal. No presente estudo investigamos o polimorfismo do exon 20 do ELN em 14 pacientes com DDC e 26 controles. A presença de mutação foi verificada por eletroforese conformacional de fita simples e sequenciamento automático. Demonstramos bandas anormais em alguns pacientes, que representaram uma mutação não conservativa: substituição de um nucleotídeo (AGT $\rightarrow$ GGT) no códon 422 do gene da ELN em cinco pacientes com DDC. Nenhum indivíduo controle estudado apresentou este tipo de mutação. Observamos uma associação significante $(P=0,003)$ desta mutação com o desenvolvimento da DDC e risco relativo 3,89 vezes maior 
(intervalo de confiança de 95\%: 2,21-6,83) dos indivíduos com esta mutação desenvolver DDC. Esta mutação troca Serina, um aminoácido não polar, por glicina, um aminoácido neutro, alterando a estrutura hidrofóbica da elastina e secundariamente a estrutura da fibra elástica. Esta alteração pode promover perda da complacência da parede intestinal e o desenvolvimento de divertículo. 
$\mathrm{RICCI}$ Jr., J. Polymorphism of exon 20 of elastin gene in individuals with colonic diverticular disease. São Paulo, 2004. 98p. PhD Thesis Faculdade de Medicina, Universidade de São Paulo.

Colonic diverticular disease (CDD) is related to civilization, industrialization and diet. Physiological studies demonstrated that increased intraluminal pressures as well as acquired structural changes of the intestinal wall seem to be decisive factors, which intensify during ageing. These changes may be due to alterations of the musculare and connective tissues and are related to collagen and elastin metabolism, which presumably can be genetically determined. It is known that patients with genetic disorders of elastin gene (ELN), such as supravalvular aortic stenosis and cutis laxa, may also manifest hernias, diverticulosis and bladder dysfunction. Recently, punctual mutations were demonstrated in ELN exon 20 of inguinal hernia patients. In the the present study, the polymorphism ELN exon 20 was tested in 14 patients with CDD and in 26 controls. Mutations were sought by singlestrand conformation polymorphism and by automatical sequence. An abnormal band was demonstrated in some patients, representing a missense mutation: a single nucleotide substitution (AGT $\rightarrow$ GGT) was detected in codon 422 in five patients with CDD. There is a substituion of serine, a nonpolar amino acid, by glycine, na uncharged one. No controls showed this punctual mutation $(P=0,003)$, and the odds ratio for development of CDD was 3.33 (95\% confidence interval:1,98-5,62). As a consequence of this substitution, the hydrophobic structure of elastin and of elastic fiber may 
promote a loss of compliance of the intestinal wall and development of diverticula. 
INTRODUÇÃO 


\section{INTRODUÇÃO}

O estudo de doenças com evidente componente genético foram historicamente realizados em sua maioria segundo a visão Mendeliana, limitando-se ao estudo de doenças com clara etiologia genética ou à tentativa de identificar relações de causa-efeito em doenças malignas. $\mathrm{O}$ surgimento da Genômica em 1987 impôs uma nova necessidade e visão para a pesquisa científica no campo da genética abrindo perspectivas para a investigação de possível envolvimento genético em doenças de alta prevalência, consideradas benignas e de alto custo sócio-econômico. $\mathrm{O}$ estudo epidemiológico e morfológico destas doenças, até o presente momento, dá como alternativas a terapia medicamentosa e/ou cirúrgica. A visão que se delineia para o futuro vem de uma nova ciência - a Genômica - que redireciona para outra terapia: a terapia gênica.

Neste contexto, encontramos a Doença Diverticular dos Cólons (DDC), enfermidade de grande prevalência, com altos índices de morbidade e mortalidade e com elevada repercussão socioeconômica. Sua etiopatogenia não é completamente conhecida, mas parece envolver fenômenos primários ou genéticos e secundários ou ambientais (ex. dieta pobre em fibras). 
Chama a atenção o fato de que a DDC apresenta-se de forma predominante no lado direito do cólon nos orientais e que a incidência aumenta quando esse grupo adota a dieta ocidental, pobre em fibras. Por outro lado a DDC quase inexiste entre os africanos de etnia negra e a incidência neste grupo aumenta quando adota a dieta ocidental. Nos ocidentais a DDC predomina no cólon sigmóide, e em menor número com distribuição universal. Tal fato é creditado ao estilo de vida ocidental, tendo como maior fator desencadeante a dieta pobre em fibras. Entretanto na Índia, apesar da dieta rica em fibras, a DDC é relativamente frequente, sugerindo que outros fatores participem, inclusive genéticos.

Os termos Doença Diverticular ou Doença Diverticular dos Cólons, por serem mais abrangentes, têm sido preferidos pela grande maioria dos autores, reservando-se as denominações diverticulose para a presença dos divertículos sem manifestações clínicas e diverticulite quando da coexistência de um processo inflamatório geralmente associado à infecção e suas complicações.

Nos últimos 20 anos sua prevalência aumentou, pela maior expectativa de vida do ser humano e pela adoção de dieta industrializada, que é de forma geral, pobre em fibras.

A presença de DDC é relativamente incomum antes dos 40 anos (5\%) e aumenta para cerca de $30 \%$ acima dos 50 anos, para $50 \%$ além dos 70 anos, chegando a $70 \%$ após os 80 anos (CASTRO e COELHO, 2004).

É sabido que os divertículos apresentam-se no intestino grosso de duas formas: congênitos e adquiridos. Os congênitos, geralmente únicos, 
chamados de divertículos verdadeiros por serem constituídos pelas três camadas da parede do cólon e os adquiridos, mais frequentes, chamados de falsos ou pseudodivertículos que são herniações da mucosa que ocorrem nos pontos de entrada dos vasos sanguíneos através da camada muscular circular do intestino. Existem dois pontos vulneráveis à herniações: o primeiro fica entre as junções longitudinais dos músculos, as tênias colônicas; o segundo na região entre os anéis do músculo circular do cólon. Na estrutura participam apenas a mucosa e a submucosa.

A DDC foi citada pela primeira vez no início do século XVIII por LITTRE (apud FINNEY, 1928), e teve ressaltada sua importância clínica em 1899 descrita por GRASER, que também chamou a atenção para o fato dela ser rara. A primeira tentativa de classificação só foi feita em 1963 por CHIFLLET e, mais recentemente, uma segunda classificação proposta em 1983 por RYAN, passou a servir de referência para os estudos genéticos.

A pesquisa sobre a etiopatogenia da DDC fundamenta-se até hoje nos estudos da associação das alterações estruturais da parede do cólon a fatores relacionados com o envelhecimento, entendido como maturação fisiológica e progressiva das estruturas sem ocasionar a perda total da função, e à dieta pobre em fibras, que levaria a alterações no bolo fecal e no trânsito intestinal, aumento da pressão intracolônica e formação de divertículos através da parede do cólon nos locais de menor resistência.

Em estudos anteriores, verificou-se que esta doença parece estar relacionada a modificações na composição qualitativa e quantitativa dos componentes estruturais da parede dos cólons e do sistema de fibras 
elásticas da parede intestinal, uma vez que a fibra elástica é o componente estrutural que da elasticidade e resistência ao tecido, influindo na complacência tecidual.

O envolvimento de um possível defeito genético do tecido conjuntivo é sugerido pelo achado de divertículos em crianças e adultos jovens com síndromes de Marfans, e de Ehlers-Danlos. Existe também uma forte relação entre a doença renal policística e divertículos perfurados, (SCHEFF et al., 1979). Embora a predisposição genética ainda deva ser totalmente explorada, sabe-se que a etnia é fator predisponente para os divertículos colônicos localizados à direita, condição comumente encontrada nas populações do Oriente, (CHIA et al., 1991). É possível que os pacientes que desenvolvem divertículos colônicos localizados à esquerda tenham uma anomalia genética ainda não detectada nos seus tecidos, ou que estejam mais predispostos ao processo natural de envelhecimento.

Muito embora os estudos relativos à etiopatogenia da DDC sejam extensos e abrangentes, diversas questões não foram elucidadas, suscitando indagações importantes, tais como :

- Por que alguns indivíduos desenvolvem divertículos em idades mais jovens?

- Por que em alguns pacientes os divertículos localizam-se no cólon direito e em outros no sigmóide e/ou de maneira universal nos cólons? - A doença diverticular dos cólons, que se revela por morfologia e manifestações clínicas diferentes, configuraria uma síndrome com 
vários espectros de apresentação e com base genética?

Em 1975, PAINTER e BURKITT descreveram esta doença como "um problema do século 20" e, em 1999, a American Society of Colon and Rectal Surgeons celebrou o centésimo aniversário da DDC. Conquanto seja uma doença antiga e frequente, a DDC continua envolta numa incompleta elucidação de sua etiopatogenia, em pleno século 21. 
REVISÃO DE LITERATURA 


\section{REVISÃO DE LITERATURA}

\subsection{Histórico}

A DDC teve sua primeira descrição no início do século XVIII por LITTRE (Tabela 1) como sendo uma expansão sacular do cólon, citado em 1793 na edição de MATHEW BAILLIE de "Mórbida Anatomia". CRUVEILHIER (1849) descreveu os divertículos como entidade morfológica, avaliando os riscos das sequelas infecciosas. GRASER (1899) introduziu o termo peridiverticulite e foi o primeiro a descrever uma diverticulite que levou à perfuração e à fístula entérica.

BEER (1904) propôs que a diverticulite era devida à impactação das fezes no colo do divertículo e CASE e QUERVAIN (1914) propuseram o termo diverticulose e descreveram as primeiras imagens radiológicas.

Vários trabalhos se seguiram estudando enemas baritados e exames post morten que identificaram um aumento na prevalência da DDC em anos subsequentes (SPRIGGS e MARXER, 1925) (FIFIELD, 1927) (PARKS, 
1969 e 1975) (PETRIE, 1972). PAINTER e BURKITT (1971, 1972), propuseram a hipótese da DDC ser causada por dieta pobre em fibras com

Tabela 1 - Revisão histórica e do aumento da prevalência ao longo do tempo da diverticulose colônica. Mimura, T. et al., 2002.

\begin{tabular}{|c|c|c|}
\hline Ano & Autor & Informes e eventos \\
\hline 1700 & Littre $^{*}$ & $\begin{array}{l}\text { Primeira descrição como "quisto externo sacular } \\
\text { do cólon" }\end{array}$ \\
\hline 1849 & Cruveilhier & Apreciou o risco de sequelas infecciosas \\
\hline 1880 & & Desenvolvimento do moinho de farinha por rolos \\
\hline 1899 & Graser & $\begin{array}{l}\text { Introduziu o termo "peridiverticulite" e sugeriu a } \\
\text { herniação da mucosa através das áreas de } \\
\text { penetração da "vasa recta" como patogénica }\end{array}$ \\
\hline 1904 & Beer & $\begin{array}{l}\text { Propos que a diverticulite era devido à } \\
\text { impactaçao das fezes no colo do divertículo }\end{array}$ \\
\hline 1917 & Drummond & Assemelhou o divertículo à hérnia inguinal \\
\hline 1925 & Spriggs e Marxer & $10 \%$ em 1.000 enemas baritados, RU \\
\hline 1927 & Fifield & $9 \%$ em mais de 10.000 séries post-morten \\
\hline 1968 & Parks & $30 \%$ em 300 post-morten \\
\hline 1972 & Petrie & 29\% em 1.170 enemas baritados, RU \\
\hline $1960-1980$ & Painter et al. & $\begin{array}{l}\text { Propos a hipótese de doença por deficiência de } \\
\text { fibra e elevada prisão intraluminal }\end{array}$ \\
\hline
\end{tabular}

* Citado em Finney, J. M. T., 1928.

com o consequente aumento da pressão intraluminal do intestino, que levaria a uma excessiva segmentação do cólon. Especularam que a possível causa da doença, estaria ligada à mudança na dieta relacionada ao desenvolvimento do moinho de rolos para farinha em 1880.

Apesar dos diversos trabalhos sobre o assunto persistem ainda muitas dúvidas quanto ao mecanismo de formação dos pseudodivertículos (GOLIGHER, 1990). 


\subsection{Etiopatogenia}

Os estudos dos hábitos alimentares mostraram existir relação entre a incidência da DDC e consumo de fibras vegetais; assim, a redução da ingestão de fibras vegetais, situação preponderante entre as populações dos países industrializados, quando associada às condições individuais predisponentes, poderá levar ao aparecimento da doença, com características clínicas e evolução peculiares (PAINTER e BURKITT, 1971 e 1975) (ALMY e HOWELL, 1980) (GUO-ZONG 1984) (FISHER et al., 1985).

As evidências atuais sobre a etiologia da DDC incluem estudos das alterações morfológicas da parede do cólon, da dieta pobre em fibras, do envelhecimento, das alterações da pressão intraluminal assim como do colágeno e da elastina, componentes da matriz extracelular (KAMM, 2002).

\subsection{Estudos morfológicos}

O estudo dos elementos estruturais da parede colônica e da sua funcionalidade, demonstrou alterações nos componentes da parede nos casos de DDC, permitindo a elaboração de algumas teorias a respeito da sua etiopatogenia. GRASER (apud GOLIGHER, 1990) em estudos de necrópsia, sugeriu que os divertículos possam ser consequência da fraqueza da parede intestinal, correspondente aos pontos de penetração dos vasos sanguíneos na camada muscular para irrigação tanto do músculo 
como da submucosa e mucosa, desde que haja pressão intraluminal suficiente. Introduziu o termo "peri-diverticulitis" para explicar as alterações anatômicas que observou.

HABERSCHON em 1857 e Sir ARBUTHNOT LANE em 1885 (Tabela 2) notaram que os divertículos ocorriam quando havia espessamento da parede intestinal e associaram a sua formação a possíveis contrações vigorosas da musculatura cólica (apud WHITEWAY e MORSON, 1985b).

DRUMOND (1917) estudou a correlação dos divertículos com os vasos sanguíneos da parede do cólon e os assemelhou à formação da hérnia inguinal.

TELLENG e GRUNER em 1917 (apud WHITEWAY e MORSON, 1985b) postularam que a inflamação dos divertículos seria responsável pelo espessamento das camadas musculares do intestino grosso.

KEITH (1910), EDWARDS (1939) e CELIO (1952) verificaram a presença de espessamento da camada muscular do cólon e correlacionaram a ocorrência dos divertículos com possível fraqueza da parede intestinal e aumento da pressão intracolônica.

Utilizando métodos radiológicos e angiográficos, NOER (1955) e SLACK (1960), verificaram correlação entre as alterações da camada muscular e os vasos sanguíneos da parede do cólon com os divertículos.

As alterações morfológicas e funcionais do cólon nos portadores de DDC e suas manifestações clínico-patológicas características serviram como base para classifcar a doença com objetivos clínicos, didáticos e fisiopatológicos, conforme propõem alguns autores. 


\section{Tabela 2 - Evolução histórica do conceito de DDC}

\begin{tabular}{|c|c|c|}
\hline Ano & Autor & Informes e eventos \\
\hline 1857 & Haberschon & \multirow{2}{*}{$\begin{array}{l}\text { Divertículos derivados do espessamento da } \\
\text { parede intestinal, associando a formação à } \\
\text { contrações da musculatura colônica }\end{array}$} \\
\hline 1885 & Arbuthnot Lane & \\
\hline 1910 & Keith & $\begin{array}{l}\text { Correlação do espessamento da camada } \\
\text { muscular do cólon à ocorrência de divertículos } \\
\text { com a factível fraqueza da parede e a elevação } \\
\text { da pressão intracolónica }\end{array}$ \\
\hline 1917 & Drumond & $\begin{array}{l}\text { Correlação dos divertículos com os vasos } \\
\text { sanguíneos da parede do cólon e os } \\
\text { assemelhou com a hérnia inguinal }\end{array}$ \\
\hline 1917 & Telleng e Gruner & $\begin{array}{l}\text { Inflamação do divertículo responsável pelas } \\
\text { lesões das camadas musculares do cólon }\end{array}$ \\
\hline 1939 & Edwards & Idem ano 1910 \\
\hline 1952 & Celio & Idem anos 1910 e 1939 \\
\hline 1955 & Noer & $\begin{array}{l}\text { Com métodos radiológicos e angiográficos } \\
\text { correlação das alterações das camadas } \\
\text { musculares e dos vasos sanguíneos do cólon } \\
\text { com os divertículos }\end{array}$ \\
\hline 1960 & Slack & Idem ano 1955 \\
\hline 1963 & Chifflet & $\begin{array}{l}\text { Classificação como congênita, hipertônica e } \\
\text { hipotônica }\end{array}$ \\
\hline 1983 & Ryan & $\begin{array}{l}\text { Classificou como Tipo Clássico (caucasiano) e } \\
\text { Tipo Novo (asiático) }\end{array}$ \\
\hline
\end{tabular}

Fonte: Mimura, T., 2002

CHIFFLET (1963) classificou a doença diverticular em três tipos:

a) Congênita ou por má formação da parede intestinal;

b) Colopatia Diverticular por Hipertonia - os portadores desta modalidade da doença apresentariam alterações dinâmicas do intestino, com hipertonia ou distonia. Seria a forma limitada ao cólon sigmóide, ocorrendo mais frequentemente em indivíduos jovens (40 a 
60 anos), cujas complicações mais frequentes variam de dores espásticas a processos infecciosos;

c) Colopatia Diverticular por Hipotonia - forma que habitualmente acomete pacientes idosos, nos quais há atrofia muscular, e os divertículos estão por todo o cólon, são numerosos e apresentam óstio diverticular largo com ampla comunicação com a luz intestinal. O quadro clínico está muito mais relacionado a alterações vasculares como hemorragia ou isquemia.

As diferenças na parede colônica entre os africanos de etnia negra e os ocidentais podem ajudar a explicar alguns dos fatores etiológicos desta condição. WATTERS et al. (1985) compararam as propriedades mecânicas do cólon em séries de necrópsias de pacientes falecidos em Edinburgo, no Reino Unido e Kampala, em Uganda. Um total de 32 espécimes foram obtidos em Edinburgo, inclusive 5 com diverticulose. Nenhum dos 20 espécimes de Kampala apresentava DDC, em razão de sua raridade. A resistência à tração, largura, espessura e tensão de ruptura foram medidas. Em ambas populações, a resistência à tração declinou com a idade. Quando o cólon esquerdo e cólon direito foram comparados, o primeiro era mais estreito, débil, menos distensível, e tinha menor resistência à tração que o direito. Quando espécimes destes países foram comparados, aqueles de Kampala eram mais fortes, mais largos em diâmetro e tinham paredes mais finas. Esses achados sugerem que o cólon da população africana de etnia negra é mais forte e, em consequência, mais resistente à deformação 
do que o cólon dos demais. Nenhuma diferença foi encontrada no grupo de Edinburgo entre os cólons com e sem diverticulose em relação a suas propriedades mecânicas.

Diferenças na distensibilidade dos segmentos colônicos foram apresentadas em estudos in vivo e in vitro. A distensibilidade é menor no cólon sigmóide e descendente e maior no ascendente e transverso.

Com base numa eventual alteração do tecido conjuntivo do intestino grosso, RYAN (1983) (Tabela 3) sugeriu a existência de dois tipos de DDC; o primeiro, com espessamento muscular, associado a complicações infecciosas, com divertículos localizados principalmente no cólon esquerdo; e o segundo, sem anomalias musculares, com divertículos ao longo do cólon, com raras complicações inflamatórias e perfurações mas, com sangramento como complicação comum, possivelmente devido às anomalias do tecido conjuntivo. Este conceito pode explicar a diferença nas características da doença nos países ocidentais e asiáticos, como é o caso das anomalias musculares e as complicações inflamatórias que são incomuns no Japão. Neste país, a diverticulose do lado direito consiste frequentemente de um único ou poucos divertículos, e se desenvolve numa idade mais jovem do que a doença do lado esquerdo. 
Tabela 3 - Classificação da DDC elaborada por Ryan (1983).

\begin{tabular}{lcc}
\hline \hline & $\begin{array}{c}\text { Tipo Clássico } \\
\text { (Caucasiano) }\end{array}$ & $\begin{array}{c}\text { Tipo Novo } \\
\text { (Asiático) }\end{array}$ \\
\hline \hline Local do divertículo & Lado esquerdo & Bilateral \\
Anomalia muscular & Notável & Ausente \\
Pressão intraluminal & Anormalmente alta & Normal \\
Tecido conjuntivo & Normal & Anormal \\
Complicações inflamatórias & Frequentes & Incomuns \\
Hemorragia & Rara & Comum \\
\hline \hline
\end{tabular}

Fonte: Mimura, T., 2002.

A pesquisa sobre a etiopatogenia da DDC fundamentada na associação das alterações estruturais é um fato que continua através da investigação das alterações morfológicas da parede do cólon.

HALSTED (apud GOLIGHER 1990) (Tabela 4 ) observou que a submucosa do cólon permanecia íntegra mesmo após a destruição das demais camadas por esmagamentos sucessivos com pinça cirúrgica. Evidenciou, dessa maneira, que a submucosa do cólon é a mais resistente das camadas que constituem a parede do intestino grosso. THOMSON et al. (1987) estudaram a parede do cólon e verificaram que a camada submucosa é composta quase que inteiramente por uma rede de fibras colágenas que se altera estruturalmente com o aumento da idade nos cólons normais, e também nos que apresentam DDC. Esses estudos sugerem que o envelhecimento seja outro fator envolvido no desenvolvimento da DDC.

A literatura documenta bem o aumento da incidência da DDC com a 
idade, assim como a progressiva mudança de estruturas da parede colônica, como a taenia coli e musculatura circular do cólon, com encurtamento propiciado pela elastose, descrito por PACE (1969) e WHITEWAY e MORSON (1985a). Esta condição, associada a uma dieta preponderantemente constipante, seria o mecanismo que estimularia o desenvolvimento da DDC.

WHITEWAY e MORSON (1985a) em estudo morfométrico e de microscopia eletrônica da parede do cólon sigmóide com DDC, demonstraram que as camadas circular e longitudinal, representadas pelas tênias do cólon, estão espessadas por diferentes razões: a tênia, como resultado de contratura seguida da deposição de elastina, e a musculatura circular, pela prolongada compressão e enrugamento provocado pelo encurtamento da tênia. Demonstraram também que a elastina estava aumentada em $200 \%$ na tênia do sigmóide com diverticulose, não se registrando alteração na quantidade de elastina da camada muscular interna comparativamente ao grupo controle.

BARROS (1999) em sua tese de doutorado, demonstrou que indivíduos com DDC hipotônica apresentam menor quantidade de fibras elásticas na parede do cólon, quando comparados aos indivíduos normais. Demonstrou também a presença de grande quantidade de fibras elásticas jovens -responsáveis pela resistência elástica- na parede do cólon de indivíduos com DDC localizada ou hipertônica.

A degradação tecidual depende da atividade de proteinases secretadas pelas células do tecido conjuntivo, incluindo as 
metaloproteinases da matriz; o equilíbrio entre a síntese e degradação da matriz é importante para a integridade tecidual, pois sua remodelação ocorre continuadamente (JACKSON et al., 1996).

Tabela 4 - Evolução histórica da fisiopatologia da DDC.

\begin{tabular}{|c|c|c|}
\hline Ano & Autor & Estudos \\
\hline 1891 & Halsted & $\begin{array}{l}\text { A submucosa é a camada mais resistente da parede } \\
\text { do cólon }\end{array}$ \\
\hline 1955 & Wess et al. & $\begin{array}{l}\text { Estrutura da parede em rede de fibras colágenas. } \\
\text { Suscetibilidade a alterações por envelhecimento e } \\
\text { moléstia diverticular }\end{array}$ \\
\hline 1966 & Pace e Whithway & $\begin{array}{l}\text { Mudanças na taenia coli e camada muscular circular, } \\
\text { com encurtamento por elastose e dieta constipante }\end{array}$ \\
\hline 1982 & Eastwood et al. & $\begin{array}{l}\text { DDC, condição normal do envelhecimento associada } \\
\text { a processo degenerativo do colágeno. }\end{array}$ \\
\hline $1985 a$ & Morson & Idem 1966 \\
\hline $1985 a$ & Whithway e Morson & $\begin{array}{l}\text { Espessamento das camadas musculares circular e } \\
\text { longitudinal. Taenia coli contraída com deposição de } \\
\text { elastina. Camada muscular circular comprimida e } \\
\text { enrugada pelo encurtamento da taenia coli }\end{array}$ \\
\hline $1985 b$ & Whithway e Morson & $\begin{array}{l}\text { Mudanças na parede são de caráter dinâmico } \\
\text { associadas às alterações do conteúdo intraluminal }\end{array}$ \\
\hline 1987 & Thonson et al. & Idem ano 1955 \\
\hline 1996 & Jackson et al. & $\begin{array}{l}\text { Degradação tecidual dependente da atividade das } \\
\text { metaloproteinase secretadas pelas células do tecido } \\
\text { conjuntivo. Equilíbrio entre síntese e degradação } \\
\text { importante para a integridade tecidual. Remodelação } \\
\text { constante }\end{array}$ \\
\hline 1999 & Barros & $\begin{array}{l}\text { Menor quantidade de fibras na parede colônica na } \\
\text { DD difusa ou hipotônica. Presença de grande } \\
\text { quantidade fibras elásticas jovens }\end{array}$ \\
\hline 2000 & Bode et al. & $\begin{array}{l}\text { Aumento da síntese do colágeno tipo III, porém não } \\
\text { no tipo I, sem esclarecimento do mecanismo nem a } \\
\text { patogênese da diverticulose }\end{array}$ \\
\hline
\end{tabular}

Fonte: Mimura, T., 2002.

Esta família de endopeptidases degrada todos os componentes da matriz extracelular, tais como colágenos, elastina e glicoproteínas. Elas são secretadas por uma variedade de células, inclusive macrófagos, células T e miofibroblastos, após a estimulação por ocitocinas e outros fatores. Entre 
esses outros fatores pode estar incluída a flora bacteriana (MACDONALD e PENDER, 1998).

\subsection{Estudos sobre a atividade motora do cólon e sua relação com as fibras vegetais}

ARFWIDSSON et al. (1964) e HUGHES (1969) (Tabela 5) em estudos morfométricos (Tabela 6) demonstraram a presença de hipertrofia em portadores de DDC incipiente e sem sinais de inflamação.

WHITEWAY e MORSON (1985b) demonstraram, em estudos ultraestruturais do cólon sigmóide com DDC não complicada, que as células musculares da parede do cólon são normais e não mostram evidências de hipertrofia ou hiperplasia como responsáveis pelo espessamento da camada muscular. Concluíram que há indícios de mudança em outros elementos estruturais da parede intestinal.

Três estudos de WESS et al. (1995) examinaram em necropsias o possível papel da dieta e dos fatores dietético-parentais nas mudanças observadas no colágeno da parede colônica. Concluíram que ocorrem alterações importantes no colágeno para a manutenção da integridade da parede colônica.

O substrato principal para a fermentação microbiana é a fibra alimentícia. Os AGCC são o principal produto final da fermentação microbiana de carboidratos e constituem a fonte de energia necessária para 
o crescimento e manutenção das funções das células colônicas (MORTENSEN e CLAUSEN, 1996).

WESS et al. (1996) trabalhando com ratos, constataram a presença de divertículos em $42 \%$ dos animais submetidos a uma dieta deficiente em fibras, e em nenhum dos ratos alimentados com dieta rica em fibras. A concentração intestinal de ácidos graxos de cadeia curta (AGCC), especialmente o butirato, foi menor nos animais com dieta pobre em fibras .

Tabela 5 - Estudos históricos de Pressão Colônica elevada vs. Dieta de Fibras.

\begin{tabular}{|c|c|c|}
\hline Ano & Autor & Estudos \\
\hline 1963 & Painter et al. & Identificação por cinerradiografia de áreas de \\
\hline 1964 & Arfwidsson et al. & $\begin{array}{l}\text { pressão elevada com aumento da segmentação } \\
\text { cólica }\end{array}$ \\
\hline 1964 & Attisha e Smith & $\begin{array}{l}\text { Atividade da pressão do cólon e do reto antes e } \\
\text { após miotomia sigmoidéia }\end{array}$ \\
\hline 1964 & Painter e Truelove & $\begin{array}{l}\text { Inexistência de diferença pressórica em } \\
\text { indivíduos normais vs doença diverticular na } \\
\text { ausência de estímulo do cólon }\end{array}$ \\
\hline 1971 & Painter e Burkitt & $\begin{array}{l}\text { Identificação de zonas associadas ao aumento } \\
\text { da pressão intracolônica devido a ingesta } \\
\text { deficiente de fibras vegetais }\end{array}$ \\
\hline 1976 & $\begin{array}{l}\text { Srivastva, Smith e } \\
\text { Painter }\end{array}$ & $\begin{array}{l}\text { Uso de relaxantes da musculatura lisa vs farelo, } \\
\text { na doença diverticular }\end{array}$ \\
\hline 1976 & $\begin{array}{l}\text { Weinreich e } \\
\text { Anderson }\end{array}$ & Pressão intraluminal no cólon sigmóide \\
\hline 1985 & Whiteway e Morson & $\begin{array}{l}\text { Ultraestrutura do cólon sigmóide com doença } \\
\text { diverticular não complicada. Indícios de } \\
\text { mudanças em outros elementos da parede } \\
\text { intestinal }\end{array}$ \\
\hline 1995 & Wess et al. & $\begin{array}{l}\text { Aumento das ligações cruzadas do colágeno em } \\
\text { razão do envelhecimento, demonstrou ser maior } \\
\text { na presença de doença divertiular }\end{array}$ \\
\hline 1996 & Wess et al. & $\begin{array}{l}\text { Comparação da presença de AGCC, } \\
\text { especialmente butirato }\end{array}$ \\
\hline
\end{tabular}


Os AGCC (ex. butirato, propionato e acetato) constituem a principal fonte energética dos colonócitos e são fundamentais na manutenção da integridade do epitélio intestinal, no metabolismo e funções celulares. Assim, os autores concluíram que a deficiência de AGCC poderia influenciar a natureza da ligação cruzada no colágeno intestinal.

\section{Tabela 6 - Sumário dos estudos sobre a pressão intracolónica. Simpson, J. et al., 2002.}

\begin{tabular}{|c|c|c|c|}
\hline Ano & Autor & Método & Principais Achados \\
\hline 1964 & Arfwidsson & $\begin{array}{l}\text { Manometria } \\
\text { sigmóide }\end{array}$ & $\begin{array}{l}\text { Pressão intracolônica aumentada em repouso e após } \\
\text { refeições quando comparada com os controles. Resposta } \\
\text { excessiva após prostigmina. }\end{array}$ \\
\hline 1964 & $\begin{array}{l}\text { Painter e } \\
\text { Truelove }\end{array}$ & $\begin{array}{l}\text { Manometria } \\
\text { sigmóide }\end{array}$ & $\begin{array}{l}\text { Pressão intracolônica basal semelhante em controles e os } \\
\text { com DDC. Aumento excessivo na pressão intracolônica da } \\
\text { região com divertículos após o uso de prostigmina, porém } \\
\text { sem diferenças de pressão nos segmentos normais do cólon } \\
\text { diverticular. }\end{array}$ \\
\hline 1965 & Painter et al. & $\begin{array}{l}\text { Radiografia e } \\
\text { manometria } \\
\text { sigmóide }\end{array}$ & $\begin{array}{l}\text { A segmentação do cólon produz aumento da pressão } \\
\text { intracolônica em áreas localizadas. }\end{array}$ \\
\hline 1969 & $\begin{array}{l}\text { Attisha e } \\
\text { Smith }\end{array}$ & $\begin{array}{l}\text { Manometria } \\
\text { retosigmóide }\end{array}$ & $\begin{array}{l}\text { Pressão intracolônica basal semelhante em controles e } \\
\text { pacientes. Aumento excessivo na pressão intracolônica do } \\
\text { cólon diverticular após prostigmina. }\end{array}$ \\
\hline 1969 & $\begin{array}{l}\text { Parks e } \\
\text { Connell }\end{array}$ & $\begin{array}{l}\text { Manometria } \\
\text { retosigmóide }\end{array}$ & $\begin{array}{l}\text { Resposta exagerada de motilidade colônica após refeições, } \\
\text { detectada com catéteres "open-tipped", porém não com } \\
\text { balões em miniatura. }\end{array}$ \\
\hline 1976 & $\begin{array}{l}\text { Weinreich e } \\
\text { Andersen }\end{array}$ & $\begin{array}{l}\text { Manometria } \\
\text { sigmóide }\end{array}$ & $\begin{array}{l}\text { Correlação significativa entre a dor de cólica abdominal baixa } \\
\text { e atividade da pressão alta após neostigmina. Atividade de } \\
\text { pressão alta não relacionada com a presença ou ausência } \\
\text { de divertículos. }\end{array}$ \\
\hline 1977 & $\begin{array}{l}\text { Weinreich et } \\
\text { al. }\end{array}$ & $\begin{array}{l}\text { Enema baritado, } \\
\text { manometria } \\
\text { sigmóide }\end{array}$ & $\begin{array}{l}\text { Correlação entre um padrão haustral aumentado e a } \\
\text { presença de divertículos. Sem relação entre a atividade da } \\
\text { pressão e o padrão haustral. }\end{array}$ \\
\hline 1988 & $\begin{array}{l}\text { Trotman e } \\
\text { Misiewicz }\end{array}$ & $\begin{array}{l}\text { Manometria } \\
\text { sigmóide }\end{array}$ & $\begin{array}{l}\text { Pressão intracolônica aumentada em repouso e após } \\
\text { refeições quando comparada com os controles. }\end{array}$ \\
\hline 1991 & $\begin{array}{l}\text { Cortesini e } \\
\text { Pantaleone }\end{array}$ & $\begin{array}{l}\text { Manometria } \\
\text { sigmóide }\end{array}$ & $\begin{array}{l}\text { Aumento significativo do índice de motilidade mais alto na } \\
\text { DDC sintomática do que na doença assintomática e nos } \\
\text { controles, antes e após as refeições. }\end{array}$ \\
\hline
\end{tabular}




\subsection{Estudos sobre o sistema de fibras elásticas}

A integridade estrutural de um tecido ou órgão é mantida pela matriz extracelular. Embora as proteínas da matriz participem ativamente em numerosos aspectos da regulação celular, elas têm sido definidas historicamente por suas propriedades físicas e adesivas.

As fibras elásticas são componentes extracelulares estruturais do tecido conjuntivo responsáveis pela elasticidade fisiológica dos tecidos. Estão presentes em todos os tecidos, sendo sintetizadas por diversas células como fibroblastos, condrócitos e células musculares lisas. Em sua constituição apresentam dois componentes: as microfibras e a elastina interligadas pelo fenômeno da elastogênese (ROSS, 1973) (JUNQUEIRA e CARNEIRO, 1979). A elastogênese começa perto da metade da gestação na maior parte dos tecidos dos mamíferos, continua com uma taxa alta até os estágios finais do feto e o período neonatal e é quase completamente reprimida na maturidade (DAVIDSON, 1986). A formação de fibras elásticas é precedida pelo aparecimento de microfibrilas, e sendo assim, pensa-se que as microfibrilas sirvam como esqueleto sobre o qual a elastina é montada (Figura 1).

As propriedades elástica e de resistência dos tecidos dos mamíferos constatadas no parênquima pulmonar, grandes vasos e pele, advém da presença de uma rede rica em fibras elásticas da matriz extracelular (ROSENBLOOM, 1984). 
Figura 1 - Descrição esquemática da deposição de elastina (ELN).

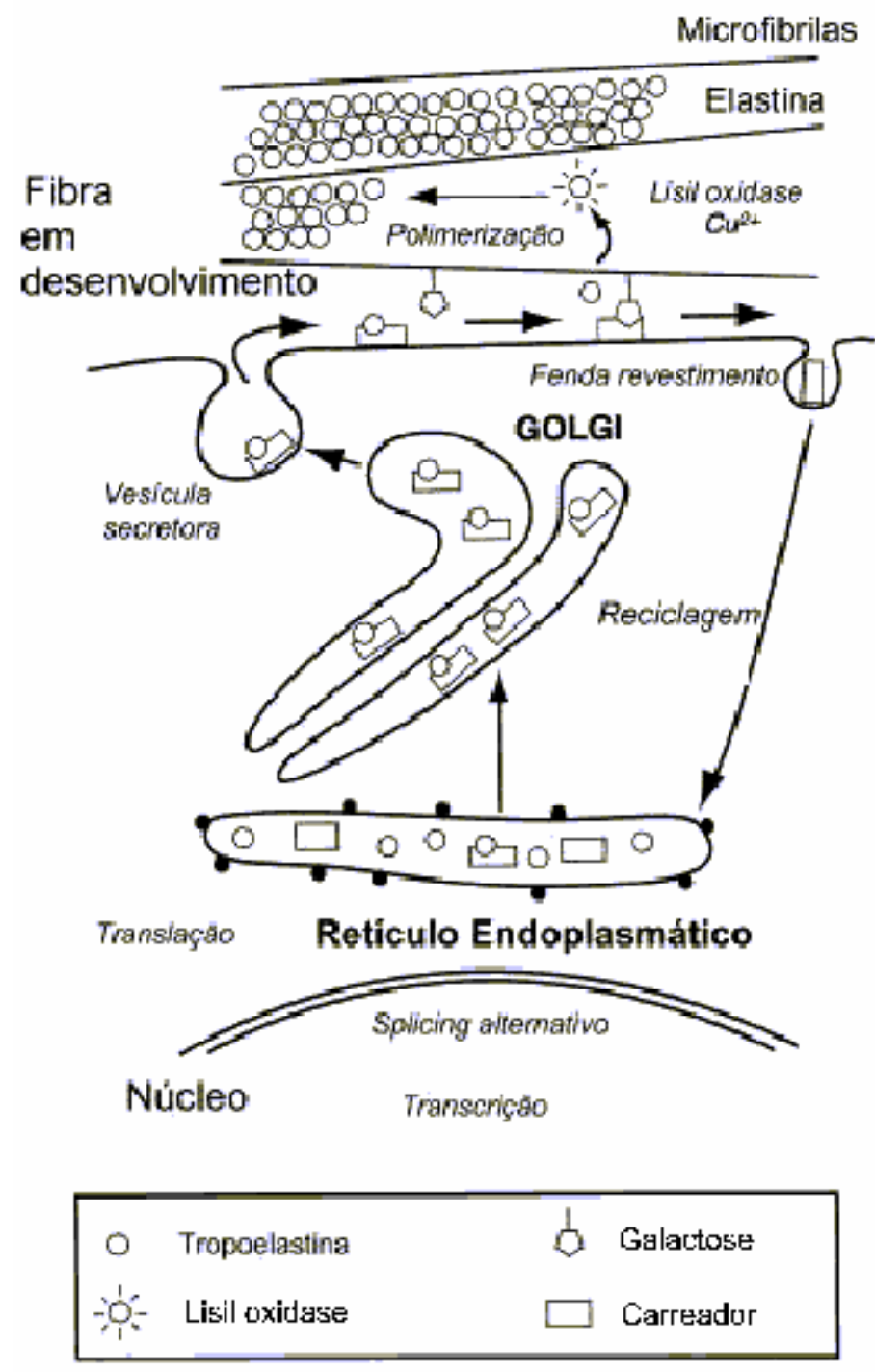

Fonte: Adaptado de Hinek, A., 1997.

O sistema de fibras elásticas é composto por três tipos de fibras (Tabela 7):

1 - As oxitalânicas, constituídas apenas por microfibrilas que se dispõem em feixes paralelos com função de resistência. Seu componente microfibrilar está constituído por microfibrilas de 10-12 nm, e é constituído por sete glicoproteínas diferentes, incluindo a fibrilina (LEE et al., 1991);

2 - As fibras elaunínicas, compostas por um arcabouço microfibrilar 
com deposição de pequena quantidade de substância amorfa, a elastina;

3 - As fibras elásticas maduras ou propriamente ditas, formadas pela deposição progressiva de elastina sobre o arcabouço microfibrilar, que são altamente insolúveis, pois apresentam grande quantidade de ligações cruzadas polipeptídicas. Estas duas últimas fibras são responsáveis pela distensibilidade reversível dos tecidos (FULLMER e LILLIE, 1958) (ROSS, 1973) (ROSS et al., 1977).

Tabela 7 - Fibras elásticas, componentes e constituição.

\begin{tabular}{lll}
\hline \hline Fibras Elásticas & \multicolumn{1}{c}{ Componentes } & \multicolumn{1}{c}{ Constituição } \\
\hline \hline Oxitalânicas & Microfibrilas 10-12 nm & 7 proteínas, inclusive fibrilina \\
$\begin{array}{l}\text { Eulanínicas } \\
\begin{array}{l}\text { Fibras Elásticas } \\
\text { Maduras }\end{array}\end{array}$ & Arcabouço microfibrilar & $\begin{array}{l}\text { Pouca substância amorfa e elastina } \\
\text { Arço microfibrilar } \\
\text { sobre o arcabõo progressiva da elastina microfibrilar }\end{array}$ \\
\hline \hline
\end{tabular}

Os primeiros elementos que se formam durante o desenvolvimento são as microfibrilas que são estruturas proteicas tubulares lançadas ao meio extracelular, onde se agrupam formando feixes. Neste agregado de microfibrilas é depositado progressivamente o componente amorfo, a elastina. Essa estrutura básica indica a forma e a direção da futura fibra elástica (ROSS e BORNSTEIN, 1969) (ROSS et al., 1977) (Figura 2).

A elastina é uma escleroproteína de composição semelhante ao colágeno, também rica em prolina e glicina, possuindo maior quantidade de valina e alanina. É uma proteína funcional, sendo o componente da fibra elástica mais resistente aos processos extrativos que o colágeno. Na sua constituição molecular apresenta cadeias de aminoácidos que promovem 
interações hidrofóbicas que são necessárias para a propriedade elástica da fibra. Por ser um produto insolúvel de monômeros de tropoelastina ligados de forma cruzada assemelha-se à borracha. Sua estrutura básica constituise de um polipeptídio linear com 72.000 daltons de peso molecular, conhecida também como tropoelastina, ou elastina solúvel (ROSS e BORNSTEIN, 1969) (JUNQUEIRA e CARNEIRO, 1979) (SANDBERG et al., 1981).

Figura 2 - Organização das fibras elásticas a nível molecular. A síntese das fibras elásticas começa pela síntese e organização no espaço extracelular das glicoproteínas estruturais: fibrilinas, glicoproteínas associadas às microfibrilas, que são produtos dos genes FBN 1, FNB 2, MFAP 1 e MFAP 2.

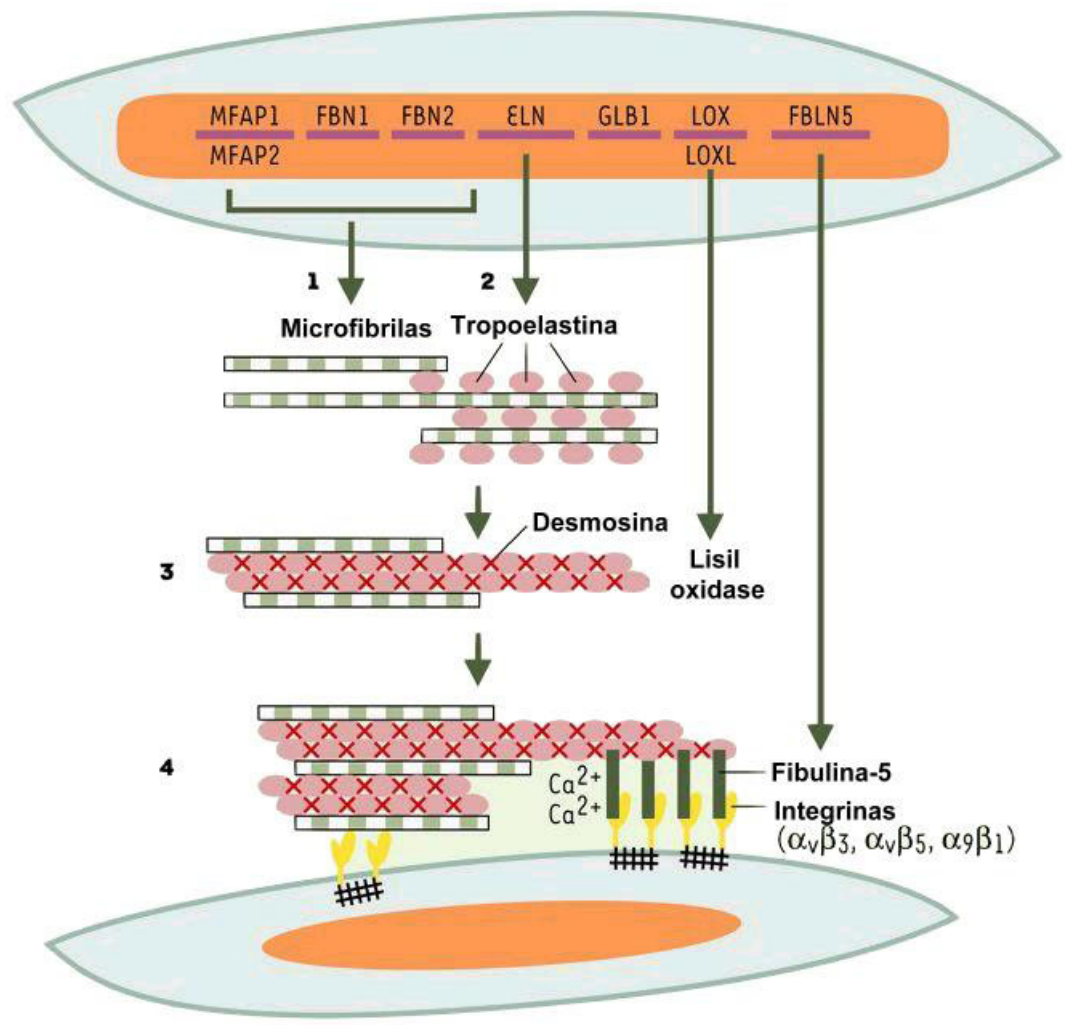

Fonte: Adaptado de Jacob, M. P., 2003.

A fibra elástica madura é formada por grande quantidade de elastina, 
que progressivamente se deposita sobre a fibra pré-madura, até atingir um conteúdo de aproximadamente $90 \%$ da fibra. (FULLMER e LILIE, 1958) (GAWLIK, 1965) (FULLMER et al., 1974) (COTTA-PEREIRA, 1976) (ROSS et al., 1977) (PANIAGUA et al., 1983).

À microscopia de luz, as fibras elásticas maduras são fibras espessas, reconhecidas seletivamente apenas pelo método de hematoxilina férrica (VERHOEFF, 1908). As fibras eulanínicas, menos espessas do que as primeiras, são reconhecidas pelas colorações de aldeído-fucsina, resorsina-fucsina (WEIGERT, 1898) ou orceína. Com a oxidação pela oxona, antes da aplicação dos três últimos corantes, puderam ser detectadas fibras mais finas do que as eulanínicas, as fibras oxitalânicas que precederiam as fibras elásticas. (FULLMER e LILLIE, 1958) (GAWLIK, 1965) (FULLMER et al.,1974 (COTTA-PEREIRA et al.,1976) (RODRIGUES, 1994).

As alterações do sistema de fibras elásticas têm sido relacionadas ao envelhecimento, exposição solar e várias outras doenças (SANDBERG, 1981). Em estudo histomorfométrico do sistema de fibras elásticas na fascia transversalis, RODRIGUES JR. (1988) demonstrou que, no envelhecimento, há diminuição de elastina nas fibras elásticas. Conclui que a redução das fibras oxitalânicas com o avançar da idade pode ser responsável por alterações na resistência dos tecidos.

Alterações do sistema de fibras elásticas com o envelhecimento têm sido demonstradas no ligamento interfoveolar da região inguinal (DANIELSEN e KOBAYASI, 1972) (BRAVERMAN e FONFERKO, 1982) 
(QUINTAS, et al., 2000), na pele, no tecido muscular esquelético (RODRIGUES, et al., 1996) (RODRIGUES e RODRIGUES JR., 2000), na cápsula esplênica (RODRIGUES et al., 1999), no ligamento interespinhoso (BARROS et al., 2002). O que se observa são alterações quantitativas e qualitativas com a redução de fibras oxitalânicas e aumento da quantidade de fibras elásticas que contêm elastina. Entretanto, estas fibras apresentam distorção da sua estrutura, mostrando-se espessas, fragmentadas e tortuosas. Esta alteração arquitetural reduz sua elasticidade original, porquanto sua força original vê-se comprometida pela redução das ligações hidrofóbicas, responsáveis pela estocagem de energia elástica. Tal alteração estrutural pode ser também devida à deposição ordenada de colágeno que comprime as fibras elásticas ou à ação da elastase tecidual, que promove a degeneração das fibras elásticas (Figura 3).

Figura 3 - Cortes histológicos do cólon de idosos com DDC hipotônica. As setas indicam fibras elástica alteradas. Barros - Tese Doutorado, 1999.

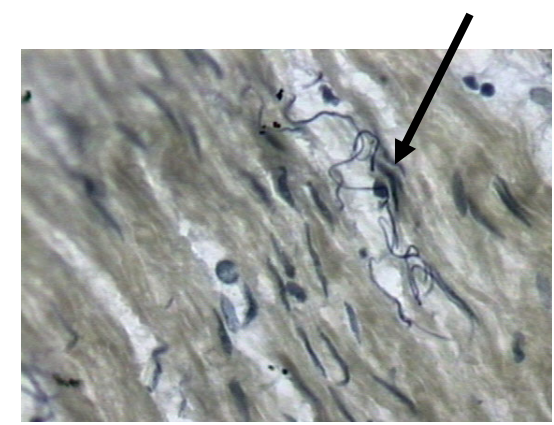

Verhoff

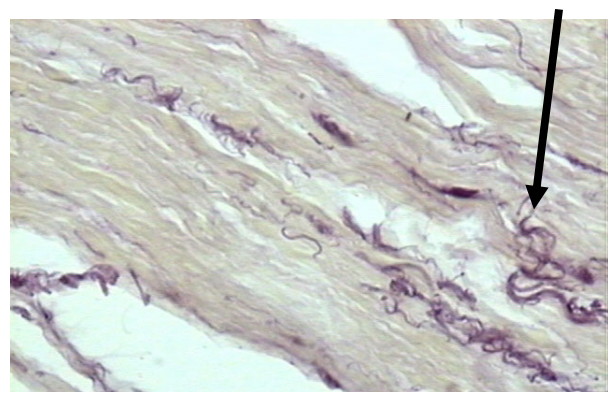

Weigert-oxona

Além do envelhecimento, outras causas podem promover a alteração 
da matriz extracelular e desta forma comprometer o bom funcionamento dos órgãos/tecidos. Assim, a perda da complacência pulmonar ocorre nos casos de hérnia diafragmática congênita, comprovada por estudos clínicos e experimentais (TANNURI et al., 1998). A redução da complacência é atribuída à elevada tensão de superfície causada por deficiência de surfactante, por aumento da concentração de colágeno e redução da densidade das fibras elásticas (LOTZE et al., 1994).

WHITEWAY e MORSON (1985) sugeriram que a elastose nas tênias pode ser a mudança inicial na DDC, embora os mecanismos responsáveis ainda não tenham sido comprovados.

\section{6 gene da elastina}

Genes são segmentos de ácido desoxirribonucléico (DNA) que codificam a sequência de aminoácidos das proteínas, especificando as suas formas e funções.

A primeira referência à possível relação direta entre uma alteração genética e uma determinada mudança na sequência de aminoácidos de uma proteína data de 1957, quando INGRAN et al. observaram que indivíduos portadores de anemia falciforme apresentavam moléculas de hemoglobina que diferiam das normais por uma simples substituição de aminoácidos.

A partir da década de 80 (Gráfico 1), novas metodologias da biologia 
molecular trouxeram a possibilidade de examinar os genes que controlam as funções dos seres vivos, responsáveis pelo fenótipo dos mesmos. Assim, o conhecimento da estrutura genômica permite realizar uma completa detecção de mutações, que podem estar relacionadas a determinadas doenças.

Gráfico 1 - Evolução do mapeamento genético. NCBI, 2004

\section{Crescimento do GenBank}

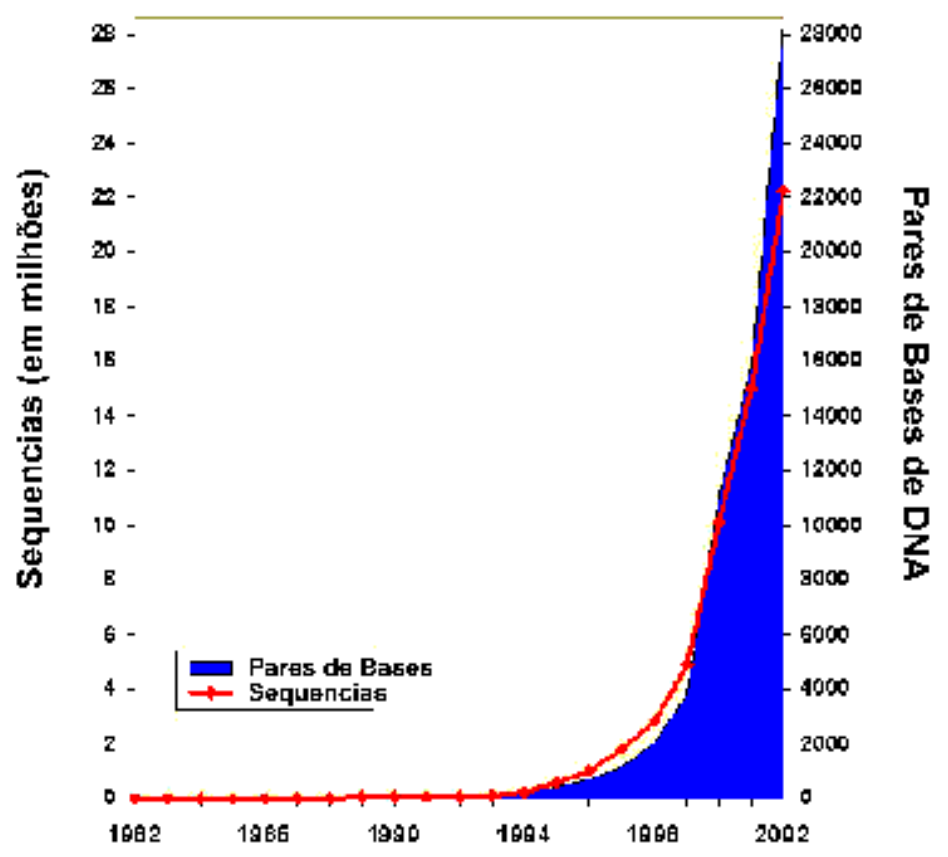

Fonte: http://www.ncbi.nlm.nih.gov/Genbank/genbankstats.html

A Reação da Polimerase em Cadeia (PCR), introduzida por MULLIS e FALOONA em 1987 dinamizou significativamente o estudo da genética, entendida como ciência que estuda genes isolados e suas funções. Por sua 
vez a Genômica é uma área do conhecimento científico surgido em 1987 com o propósito de reunir o estudo das funções e interações de todos os genes de um determinado organismo (GUTTMACHER e COLLINS, 2002).

Os dados atuais indicam que o genoma inclui aproximadamente 35.000 genes identificados dos 70.000 possíveis de acordo com o GenBank-NCBI-NIH (2003), distribuídos de maneira não uniforme nos cromossomos nucleares e mitocondriais. Somente metade desses genes tem padrões de sequência de DNA sugestivos de possíveis funções, sendo que um mesmo gene pode ser responsável pela formação de várias proteínas distintas. Mutações conhecidas por causar doenças foram identificadas em cerca de 1.000 genes, embora qualquer gene tenha potencial para causar doença, se alterado substancialmente (GUTTMACHER e COLLINS, 2002).

A localização específica de um gene ao longo do cromossomo, denominada "locus", pode ser mapeada. Convencionou-se indicar sua posição em relação ao centrômero, ponto de constrição primária que divide os cromossomos em duas porções, denominadas de braço curto "p" e braço longo "q".

Para que ocorra a formação protéica, o DNA que contém a informação codificada sobre os elementos constitutivos da proteína a ser sintetizada serve de molde para a síntese de uma molécula de ácido ribonucléico mensageiro (mRNA), num processo denominado "transcrição"; em seguida, ao levar essa informação genética do núcleo à zona citoplasmática de síntese proteica, é o mRNA que serve de molde para a 
síntese da cadeia polipeptídica codificada, fenômeno designado como "tradução" .

Na estrutura gênica, os "exons" correspondem à região codificadora da proteína, ou seja, a região que é transcrita, dando origem à proteína, enquanto os "introns", são eliminados no processo de transcrição e não fazem parte do RNA maduro. As unidades compostas de três bases nitrogenadas dispostas numa sequência específica na fita de DNA ou RNA é denominada códon. No processo de tradução cada códon determina a agregação de um determinado aminoácido no processo de síntese proteica, ou sinaliza o ponto de início ou término desse mesmo processo; assim, ao códon TCA (Timina-Citosina-Adenina ) corresponde o aminoácido Serina, enquanto que TTA (Timina-Timina-Adenina) implica adição de leucina à proteína em formação.

O caráter de absoluta especificidade da informação a ser transmitida, é fundamental para a compreensão do conceito de "mutação" e sua importância. Isto, porque qualquer que seja a causa que leve à distorção da informação contida no código original, pode ter como consequência a substituição ou a não incorporação de aminoácido(s) na proteína em formação, resultando em possíveis alterações estruturais e funcionais nos tecidos onde houver expressão desta proteína. Embora as mutações possam causar doenças por vários mecanismos, o mais comum é a perda da função, que modifica o fenótipo do indivíduo por diminuição da quantidade ou da qualidade funcional de uma determinada proteína (GUTTMACHER e COLLINS, 2002). 
Em termos puramente estruturais, cerca de $59 \%$ de todas as mutações responsáveis por doenças genéticas no homem, são as chamadas "mutações pontuais", que envolvem a troca de uma única base nitrogenada na sequência de um códon, podendo acarretar resultados diferentes, entre os quais, a substituição do aminoácido, originariamente previsto por outro e continuando com o processo normal de leitura ("missense mutation"). A substituição do códon original por um códon de parada prematura, interromperá, naquele ponto, a síntese proteica ("nonsense mutations").

Outras mutações, estimadas em 16\%, responsáveis por doenças genéticas humanas, ocorrem por "microdeleção", mecanismo mediante o qual se verifica a perda de um fragmento do DNA, contendo um ou mais pares de bases que codificariam determinada(s) proteína(s); o restante das mutações conhecidas se expressam sob a forma de inserções, duplicações, inversões, expansões e rearranjos complexos da sequência gênica (COOPER, 2002) .

Considerando a repercussão funcional no indivíduo acometido de doença genética, com alteração ou não do seu "fenótipo", muitas das variantes aleatoriamente introduzidas na sequência do genoma humano, não têm qualquer efeito pois pode ocorrer a substituição de um códon por outro que codifica o mesmo aminoácido ("silent mutations"), ou a substituição do aminoácido por outro com propriedades físico-químicas semelhantes, que induz pouca modificação na função da proteína, sendo ambas as situações designadas como "mutações conservativas". Ao 
contrário, as "mutações não conservativas" levam à troca de um aminoácido por outro de propriedades diferentes, acarretando alteração na função da proteína e consequentemente do fenótipo.

Para evitar a alta frequência de mutações e a instabilidade geral do genoma, existem mecanismos bloqueadores de determinadas fases do ciclo de reprodução celular dos mamíferos, até a ocorrência de reparação do DNA danificado, num processo chamado nucleotídeo "excision repair". O mecanismo envolve a ativação da proteína p53, considerada por essa razão "guardiã do genoma humano". A capacidade de corrigir as distorções do DNA é fundamental por sua capacidade de suprimir o desenvolvimento de tumores. A capacidade de correção diminui com o envelhecimento, o que explicaria o aumento da taxa de mutações induzidas por radiação ultravioleta com o consequente aumento na prevalência de câncer da pele nos idosos (GOUKASSIAN et al., 2000).

Os genes contêm múltiplos íntrons ou sequências não codificadoras, que correspondem a dez vezes a quantidade dos exons constituintes do mRNA. Um processo chamado "splicing" forma uma alça da região intrônica, que aproxima dois exons contidos na mesma fita do mRNA com a posterior eliminação do fragmento da fita contido na região intermediária. O "splicing alternativo" representa uma maneira importante de regulação gênica tecidoespecífica, uma vez que a possibilidade de formar sequências distintas a partir de pontos alternativos de "splicing" de um mesmo gene, pode induzir a produção de diferentes isoformas de uma mesma proteína (COOPER, 2001) (Figura 4). 
Figura 4 - A estrutura da elastina é dinâmica. A imagem apresenta a estrutura tridimensional da molécula de elastina, em especial a ligação cruzada (ponteado). Imagem cedida por Debelle e Tamburro, 1998.
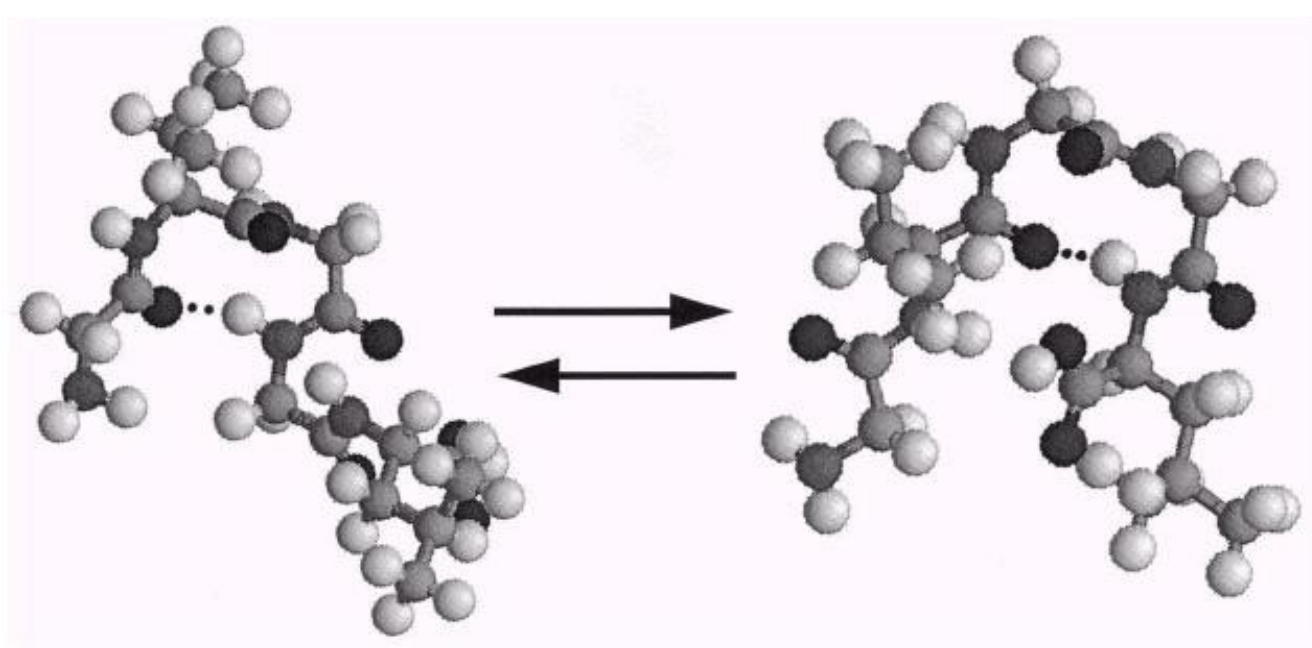

A determinação da estrutura primária das fibras elásticas só foi possível após o isolamento, em tecido de porcos deficientes em cobre, de uma substância intermediária solúvel, a tropoelastina (SANDBERG et al., 1969, FOSTER et al., 1973). O ácido desoxirribonucléico complementar (cDNA ) da elastina, como é chamado o DNA obtido in vitro a partir do mRNA, foi isolado por INDIK et al. (1987). A partir do cDNA, foi deduzida a sequência completa dos aminoácidos da tropoelastina humana (FAZIO et al.,1988).

Os primeiros estudos mapearam o gene da elastina (ELN) no cromossomo 2 (EMANUEL et al., 1985). Estudos posteriores demonstraram que o gene da ELN encontra-se na região proximal do braço longo do 
cromossomo 7 no locus 7q11.23 (Figura 5), apresentando 34 exons que ocupam 47Kb do DNA e estão separados por extensas regiões intrônicas (FAZIO et al., 1991; FOSTER et al., 1993; TASSABEHJI et al., 1997). Consequentemente, a relação íntron:exon, de aproximadamente 19:1, é elevada (BASHIR et al., 1989) (Figura 6) .

Até a presente data, três genes estão reconhecidamente envolvidos na produção das fibras elásticas: o gene da ELN no cromossomo 7 (TASSABEHJI et al., 1997), o gene da fibrilina (FBN) alojado no cromossomo 15 (MAGENIS et al., 1991) e o gene da fibulina-5 (FBLN5) mapeado no cromossomo 14 (KOWAL et al., 1999). A partir da definição da estrutura de tais genes, mutações pontuais, haploinsuficiência ou mudanças na transcrição do mRNA têm sido identificadas como causas de síndromes bem definidas, ou de alterações teciduais isoladas, fornecendo as bases para a investigação do envolvimento do gene da ELN em diversas afecções.

A síndrome de Marfan é uma desordem autossômica dominante, caracterizada por manifestações nos sistemas cardiovascular, esquelético e ocular. As principais complicações cardiovasculares são a formação de aneurismas e a dissecção da aorta torácica, preferencialmente na porção ascendente. O substrato genético da síndrome de Marfan é a ocorrência de mutações ao longo do gene da FBN-1, caracterizadas principalmente por troca de aminoácidos, resultando em prejuízo da elastogênese (MILEWICZ et al., 1996). 
Figura 5 - 0 cromossomo 7 contém aproximadamente 1.800 genes e acima de $\mathbf{1 5 0 . 0 0 0}$ milhões de pares de bases, dos quais $95 \%$ já foram sequenciados. A figura sinaliza a localização de alguns genes responsáveis pelas patologias apontadas.

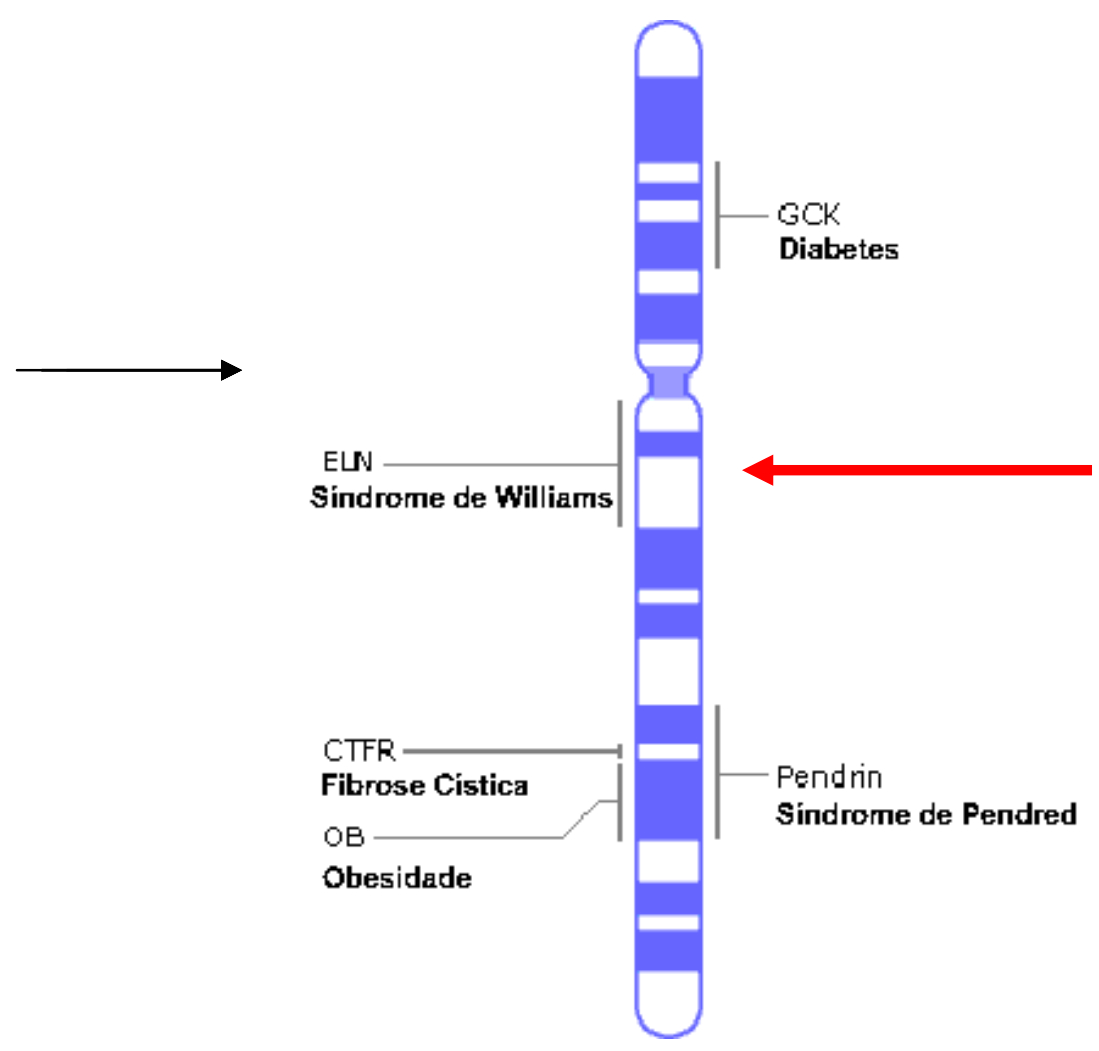

Fonte: http://www.ncbi.nlm.nih.gov/Genbank/genbankstats.html Acessado em 5 de janeiro de 2004. 
Figura 6 - Mapeamento do cromossomo 7.
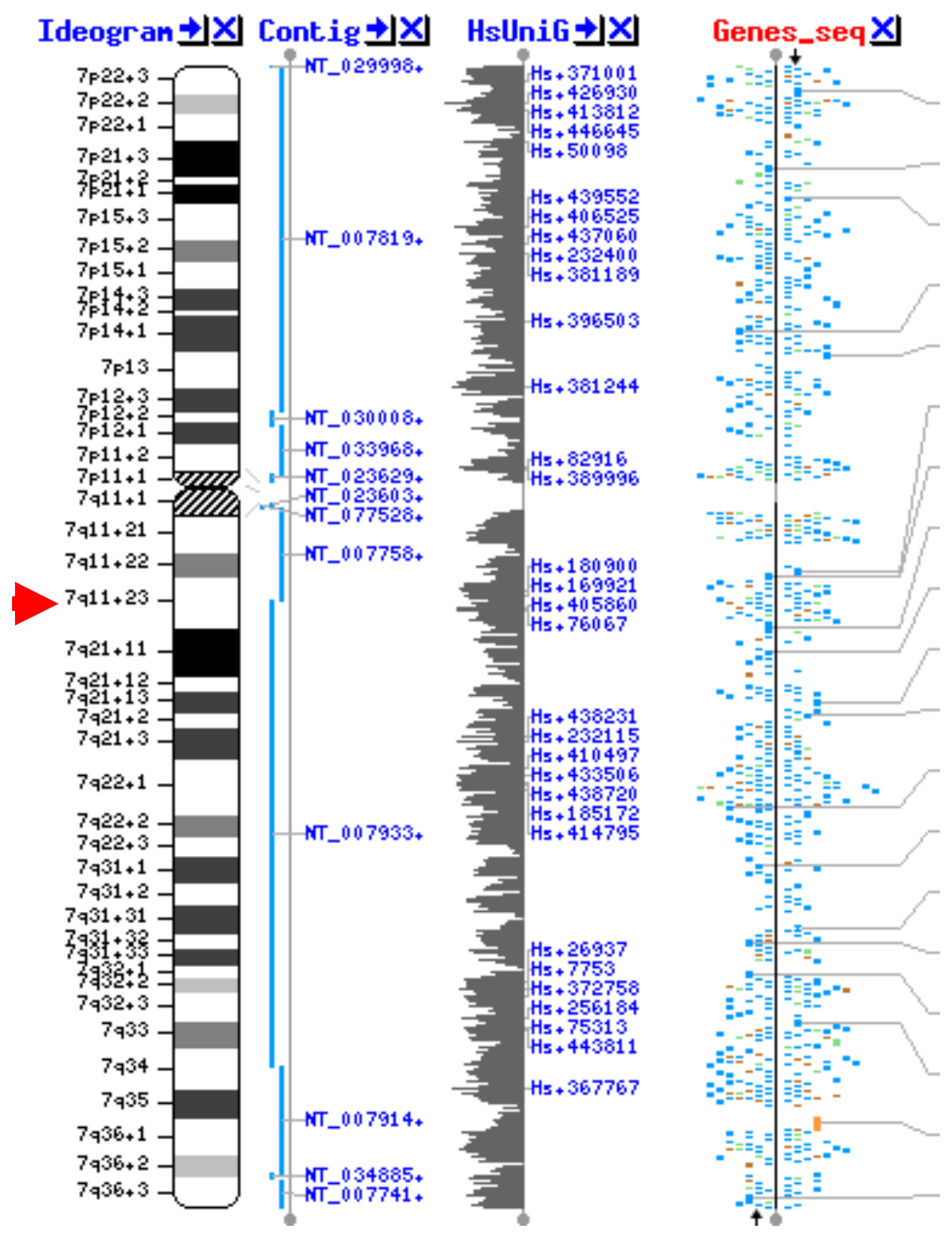

Fonte: http://www.ncbi.nlm.nih.gov/Genbank/genbankstats.html Acessado em 5 de janeiro de 2004. 
A cutis laxa hereditária compreende um grupo heterogêneo de desordens do tecido conjuntivo, caracterizadas por frouxidão cutânea, com envolvimento variável dos órgãos internos e decorre da deficiência de fibras elásticas que apresentam marcante desorganização. A homozigose para uma mutação no gene da FBLN5 resulta numa severa forma da doença em ratos (YANAGISAWA et al., 2002) e em humanos (LOEYS et al., 2002).

A elastina está constituída por um complexo de proteínas hidrofóbicas com ligações cruzadas, sintetizadas a partir de uma única cópia do gene da ELN mediante a utilização alternada de diversos exons (PIERCE et al., 1990). O produto inicial da elastina é a tropoelastina, um polipeptídeo de $72 \mathrm{Kda}$ com estrutura que alterna domínios hidrofóbicos e ligações cruzadas derivadas da oxidação de resíduos de lisina por uma enzima dependente de cobre, a "peptidil-lisil oxidase" (PARTRIDGE et al., 1966; MILLER et al., 1965). Este domínio hidrofóbico forma uma estrutura frouxa responsável pela resistência da proteína. Após a secreção, as cadeias individuais de tropoelastina são ligadas de forma covalente para formar uma rede de fibras elásticas altamente insolúvel. Estudos têm sugerido que as ligações cruzadas distintas e os domínios hidrofóbicos da elastina são codificados em exons separados. Os domínios que são apontados como determinantes dessas ligações cruzadas encontram-se nos exons $4,6,8$, 10, 12, 15, 17, 19, 20. 21, 23, 27, 29 e 31 (TASSABEHJI et al., 1997).

$\mathrm{Na}$ cutis laxa foi identificada uma mutação no exon 32 do gene da ELN que determinou a substituição de 37 aminoácidos da cadeia proteica por uma nova sequência com 62 aminoácidos (TASSABEHJl et al., 1998). 
Neste estudo, os autores verificaram uma fragmentação da elastina através da microscopia eletrônica e uma redução na deposição da elastina na derme dos pacientes. A tropoelastina depositada apresentava modificação em suas ligações cruzadas que reduzia sua capacidade de recolhimento e como resultado a pele apresenta características de lassidão. ZHANG et al., (1999) demonstraram mutação no exon 30 do gene da ELN na síndrome de cutis laxa congênita, sendo responsável pelas alterações quantitativas e qualitativas da elastina nos tecidos.

Uma outra forma de verificar a expressão do gene da ELN é através do estudo da concentração de mRNA. Assim, é possível sugerir que a bexiga fibrótica não complacente dos pacientes com mielomeningocele é resultado da grande deposição de colágeno no músculo detrusor, devido a pequena quantidade de fibras elásticas, decorrente da baixa concentração de mRNA da elastina e a baixa regulação transcricional (DJAVAN et al., 1998).

A expressão de cada um dos exons de um gene pode ter ação diferenciada. Foi verificada a presença de macrófagos na neoíntima das artérias atingidas pela hipertensão pulmonar (LIPTAY et al., 1993). A migração destas células para a neoíntima pode ser decorrente da atividade do exon 26 do gene da ELN (BISACCIA et al., 1998).

O exon 26 codifica um domínio hidrofóbico e outro altamente hidrofílico, e a ausência do segundo determinaria moléculas de tropoelastina menos sujeitas à ação da lisiloxidase dificultando a elastogênese. Alguns autores sugerem que a expressão do exon 26 pode 
estar aumentada na elastólise, no processo de envelhecimento e em doenças da fibra elástica, representando um marcador de dano tissular (WEISS e VRHOVSKI, 2001).

Como a elastina é o principal componente da aorta e das grandes artérias, a deleção de grande parte ou de todo o gene da ELN tem sido descrita em pacientes com estenose aórtica supravalvar (EASV) (MORRIS, 1998). Esta doença é caracterizada pelo estreitamento congênito da aorta ascendente, que progressivamente leva à falência do coração e morte precoce, o que justifica a correção cirúrgica na infância. Ela ocorre esporadicamente ou como condição familiar em virtude de herança autossômica dominante (MENG et al., 1998; EISENBERG et al., 1964).

Os mecanismos que regulam a expressão do gene da ELN nos fibroblastos não estão completamente esclarecidos. Um dos agentes estimuladores da expressão do mRNA da elastina em humanos é o fator de crescimento beta 1 (TGF- $\beta$ 1), encontrado em quantidade 4 ou 5 vezes maior em neonatos do que em adultos (MCGOWAN et al., 1997). Por outro lado, a interleucina-1 diminui a transcrição do mRNA da elastina nos fibroblastos do pulmão de ratos (BERK et al., 1991). Foi demonstrado que o fator de necrose tumoral alfa (TNF- $\alpha$ ) tem ação semelhante nos fibroblastos da derme humana (KAHARI et al., 1992).

A elastina é o componente principal das grandes artérias correspondendo a 28-32\% do peso seco da aorta. Entretanto, como constatado em outros genes, a regulação transcricional do gene da ELN pode variar nos diferentes tecidos e até mesmo entre diferentes artérias. Em 
cultura de células da musculatura lisa de jovens portadores da rara doença de Moyamoya, de causa desconhecida que induz a progressiva oclusão bilateral do leito distal das artérias carótidas internas, foram detectados níveis aumentados de mRNA do gene da ELN e maior resposta ao TGF- $\beta 1$ exógeno, indicando maior transcrição do gene da ELN e, consequentemente, maior produção proteica e o espessamento gradativo da íntima (YAMAMOTO et al., 1997).

A síndrome de Williams (SW) é uma doença onde ocorre deleção de genes contíguos, causada pela haploinsuficiência dos genes localizados na posição 7q11.23 (MENG et al., 1998). A SW é decorrente de deleção de gene contíguo ao ELN em 7q11.23. Quando afetado o gene da ELN dá origem a alterações que causam EASV (EAWART et al. 1993). Pacientes com SW são hemizigotos para o gene da elastina, são indivíduos retardados, tem face dismórfica, anomalias cardíacas, baixa estatura e hipercalcemia infantil (MORRIS et al., 1988). Outros fenótipos incluem hérnia, voz rouca, anomalias das articulações e envelhecimento precoce da pele.

NICKERSON et al. (1995) relataram que aproximadamente $90 \%$ dos pacientes com SW têm deleção do gene da elastina e somente $5 \%$ tem EASV severa. Não está claro se as anomalias faciais e outras características da SW podem também ser atribuídas à haploinsuficiência do gene da ELN mais do que à deleção ou silêncio de outros genes contíguos ao lócus da elastina.

Não se conhece a proporção de EASV que tem anomalias no lócus 
do gene da ELN, nem que tipo de mutação do gene da ELN causa EASV, nem que categorias de mutação causam os diferentes problemas do tecido conjuntivo. Com o objetivo de identificar estas questões TASSABEHJI et al. (1997) realizaram uma varredura do DNA genômico, identificando a completa estrutura do gene da ELN. Definiram toda a toda a estrutura exonintron do Gene da ELN e verificaram que mutações pontuais no gene da ELN podem causar EASV.

Recentemente foi descrita alta prevalência de mutações pontuais no exon 20 do gene da ELN em indivíduos com hérnia inguinal, caracterizadas por dupla troca no códon 404 que, de fenilalanina (TTT) passou a codificar serina (TCC) e no códon 422 substituiu serina (AGT) por glicina (GGT); postulou-se que, por estar o exon 20 relacionado ao domínio hidrofóbico da molécula da ELN (TASSABEHJI et al., 1997), essas alterações poderiam tornar a proteína mais hidrofílica, favorecendo a ação de enzimas proteolíticas e contribuíndo para o enfraquecimento tecidual e o desenvolvimento de hérnia (YOO, 2003). 


\section{OBJETIVO}




\section{OBJETIVO}

Estudar e analisar a ocorrência de mutações no exon 20 do gene da elastina localizado no cromossomo 7 do DNA genômico de indivíduos adultos com doença diverticular dos cólons. 
CASUÍSTICA E MÉTODOS 


\section{CASUÍSTICA E MÉTODO}

\subsection{Casuística}

Foi estudado o ácido desoxirribonucléico (DNA) genômico de 40 indivíduos, de ambos os sexos, distribuídos em 02 grupos distintos a saber: 14 indivíduos portadores de DDC, com idade entre 35 e 77 anos $(59,28 \pm$ 11,06) e 26 indivíduos controles com idade entre 39 e 62 anos $(47,26 \pm$ 11,55).

Foram excluídos indivíduos que apresentavam diagnóstico prévio de hérnia inguinal, aneurisma ou qualquer doença do tecido conjuntivo. Todos os indivíduos do estudo fizeram colonocospia para diagnóstico ou exclusão de DDC. 


\subsection{Método}

\subsubsection{Extração do DNA genômico}

Após o consentimento autorizado dos pacientes (protocolo CAPPesq. $\mathrm{n}^{\circ}$ 222/03), foram colhidos aproximadamente $10 \mathrm{ml}$ de sangue venoso periférico de cada indivíduo, com auxílio de dois tubos a vácuo contendo $5 \%$ de ácido etilendiaminotetracético (EDTA). $\mathrm{O}$ sangue foi então homogeneizado e as amostras foram identificadas por códigos compostos pela letra $(R)$ e números, e prontamente enviadas ao laboratório (Laboratório de Anatomia Médico-Cirúrgica LIM02 HC-FMUSP).

De cada amostra foi extraído o DNA genômico, conforme protocolo descrito por Miller et al. (1988), a saber:

1. O sangue foi homogeneizado e colocado em tubo com fundo cônico, completando-se até $50 \mathrm{ml}$ com tampão de lise de hemáceas e plaquetas "Bloodlysis" $\left(\mathrm{NH}_{4} \mathrm{Cl} 1550\right.$ mM; KHCO 3100 mM; EDTA 10 $\mathrm{mM} ; \mathrm{pH} 7,4)$. Os tubos foram agitados e deixados em banho de gelo por 30 minutos para romper a membrana das células contidas na amostra.

2. Em seguida as amostras foram centrifugadas a 1800 rotações por minuto (rpm) por 15 minutos. O sobrenadante foi descartado e o precipitado foi ressuspendido em $10 \mathrm{ml}$ do tampão "Bloodlysis" e centrifugado novamente por 5 minutos a $1800 \mathrm{rpm}$. 
3. O sobrenadante foi novamente descartado e o precipitado ressuspendido em $3 \mathrm{ml}$ de tampão de lise de núcleos dos leucócitos "Nucleolysis" (Tris-HCl 100 mM; NaCl 4M; EDTA 20 mM; pH 8,2), contendo $100 \mu \mathrm{l}$ de proteinase $\mathrm{K}(10 \mathrm{mg} / \mathrm{ml})$ e $300 \mu \mathrm{l}$ de dodecyl sulfato de sódio (SDS) a 10\%.

4. O material foi então incubado por aproximadamente 14 a 16 horas "over-night" a $37^{\circ} \mathrm{C}$. Este procedimento auxilia a quebra dos núcleos das células e a exposição do DNA. Após a incubação foi acrescentado $1 \mathrm{ml}$ de $\mathrm{NaCl} 6 \mathrm{M}$ e o material foi centrifugado por 20 minutos a $2500 \mathrm{rpm}$.

5. Após este procedimento, o DNA foi precipitado com etanol absoluto e resgatado com o auxílio de um capilar de vidro. O DNA foi transferido para um tubo "eppendorf" de $1 \mathrm{ml}$, onde foi lavado com etanol $70 \%$ e dissolvido em $100 \mu$ l de TE (Tris-HCl 10mM; EDTA 1 $\mathrm{mM} ; \mathrm{pH} 8,0)$. O DNA foi então incubado por 30 minutos a $65^{\circ} \mathrm{C}$ e guardado em geladeira a $8-10^{\circ} \mathrm{C}$.

\subsubsection{Determinação espectrofotométrica do DNA}

Após a extração, alíquota diluída 1:1000 em H2O foi quantificada através da Densidade Ótica (OD) em espectrofotômetro Gênesis 5 (Spectronic) em comprimento de onda de OD260/OD280 nm. 
A razão de leitura entre $260 \mathrm{~nm}$ e $280 \mathrm{~nm}$ forneceu uma estimativa da pureza do DNA que variou entre 1,8 a 2,0 (MILLER et al. 1988).

\subsection{Amplificação do DNA genômico pelo PCR (Polymerase Chain Reaction, reação em cadeia da polimerase)}

A amplificação do exon 20 do gene da ELN, localizado no cromossomo 7q11.23, que ocupa 47 kb do DNA genômico, foi obtida através da reação de PCR utilizando-se fragmentos de RNA iniciadores ou "primers" para amplificação do exon. Os "primers" foram sintetizados pela Life Technologies do Brasil LTDA, utilizando-se oligonucleotídeos das extensões 5'- 3' segundo a descrição de Tassabehji et al. (1997).

\section{Exon 20}

Primer Foward 5' - CTC TTT CCC AAT CCA TCA GCA TC - 3'

Primer Reverse 5' - CCC ATC CCT TCT CAA CCC ATG TC - 3'

Para cada reação de PCR foi preparada a seguinte solução: solução de DNTPs ( $4 \mu \mathrm{l}$ dATP, $4 \mu \mathrm{l}$ dCTP, $4 \mu \mathrm{l}$ dGTP, $4 \mu \mathrm{d}$ dTTP). Solução PCR: 2,5 $\mu \mathrm{l}$ de Buffer (Gibco BRL), 1,0 $\mu \mathrm{l}$ da solução de DNTPs, 2,5 $\mu \mathrm{l}$ de DMSO (Dimetilsulfoxido) puro; 0,3 $\mu$ de cada primer (F e R); 0,3 $\mu$ l de Taq ( Taq DNA polimerase); 2,0 $\mu$ l do DNA a ser examinado; $16,1 \mu$ le água Milli $Q$. Todo o procedimento foi realizado em banho de gelo. O tubo "eppendorf" 
contendo a mistura foi colocado no termociclador PTC 100 (MJ Research) perfazendo 27 ciclos padronizados $\left(95^{\circ} \mathrm{C} ; 94^{\circ} \mathrm{C} / 63^{\circ} \mathrm{C} / 72^{\circ} \mathrm{C} ; 72^{\circ} \mathrm{C}\right)$. Ao término dos ciclos, o termociclador resfriou-se e manteve a temperatura de $4^{\circ} \mathrm{C}$. A seguir o produto de PCR foi armazenado em geladeira a $8-10^{\circ} \mathrm{C}$.

O sucesso da amplificação do produto de PCR foi verificado através de visualização do produto em eletroforese de gel de agarose. Para tal, uma amostra do produto de amplificação foi aplicada em gel de agarose $2 \%$, submetida à corrente de $80 \mathrm{~V}$ por 40 minutos. Após o tempo de corrida, o gel foi corado com brometo de etídeo e a banda do produto foi visualizada sob luz ultra-violeta (Figura 7).

Figura 7 - Polimorfismo conformacional de simples fita. Eletroforese em gel de agarose $2 \%$. A seta indica a localização do gene.

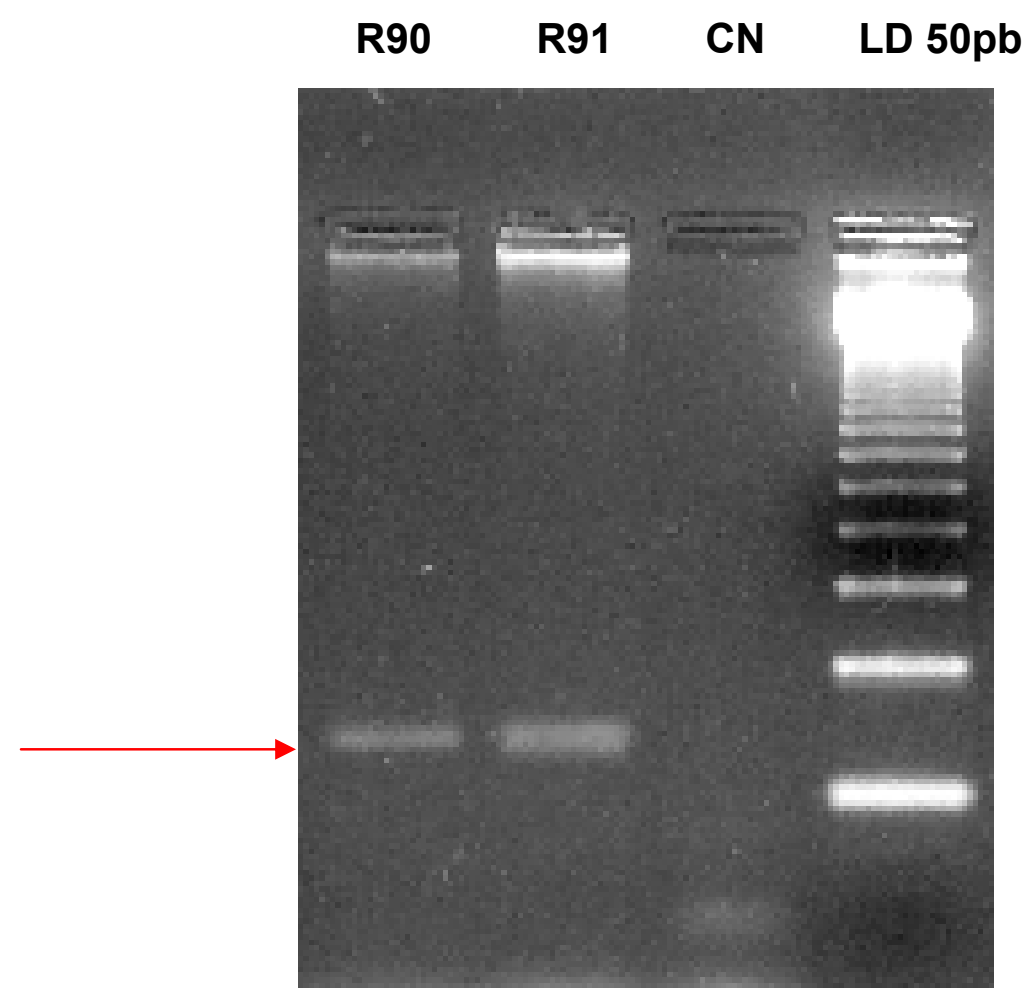




\subsection{Análise do polimorfismo do gene da Elastina pelo SSCP (SINGLE STRAND CONFORMATION POLYMORFISM, polimorfismo conformacional de simples fita)}

O experimento foi realizado conforme o método descrito por ORITA et al. (1989). Para a detecção de alterações de um par de bases em um fragmento de DNA devido a mutações ou polimorfismos, através da alteração na mobilidade da simples fita de DNA, o material foi aplicado em gel de poliacrilamida $10 \%$. A corrida eletroforética foi realizada por 16 horas em corrente constante de $25 \mathrm{~V}$ à $4^{0} \mathrm{C}$.

Após a corrida o gel foi submetido à coloração pela prata. $\mathrm{O}$ gel foi mergulhado em etanol durante 8 minutos, depois em ácido nítrico $1 \%$ durante 3 minutos. O gel foi lavado em água destilada ultra-pura "Milli Q". Em seguida mergulhou-se o gel em solução de nitrato de prata por 20 minutos. Novamente o gel foi lavado em água Milli Q. A seguir, o gel foi mergulhado em Developer I e Developer II, até que as bandas surgissem coradas. Para finalizar o processo, o gel é mergulhado em ácido acético a $10 \%$ durante 5 minutos e lavado em água Milli $Q$ e deixado a secar. Os géis foram fotografados para documentação.

Após a coloração do gel as bandas presentes foram analisadas comparando-se as bandas de indivíduos controles com pacientes com DDC. As amostras que demonstraram diferenças na posição das bandas foram submetidas ao sequenciamento. 


\subsection{Sequenciamento do exon 20 do gene da elastina}

Após a purificação do produto de PCR, utilizando-se "kit" de purificação para produtos de PCR aplicados em gel de agarose (Concert Nucleic Acid Purification System - Life Tecnologies). A reação de sequenciamento foi preparada com a seguinte solução: 2 ul de produto de PCR purificado; 1 ul de primers; 2ul de BigDye (Applied Biosystems); 1 ul de tampão. A PCR foi realizada em termociclador PTC-100 com 24 ciclos de $96^{\circ} \mathrm{C}$ por $10 \mathrm{seg}, 50^{\circ} \mathrm{C}$ por 5 seg e $60^{\circ} \mathrm{C}$ por 4 minutos. Após a reação o produto de sequenciamento foi precipitado. O produto foi então submetido a lavagens com etanol e ressuspendido em 1,5ul da solução: formamida 95\%, EDTA $20 \mathrm{mM}$, bromofenol azul 0,05\%, xilenocianol 0,05\% e aplicado no gel de poliacrilamida e submetido a eletroforese no sequenciador automático ABI-377 (Perkin Elmer).

\subsection{Análise Estatística}

A análise estatística das frequências genotípicas do exon 20 do gene da ELN foi determinada para os indivíduos em estudo. Estes resultados foram analisados através do Teste Exato de Fisher e pelo cálculo da razão de chance (odds ratio). O erro do tipo I foi limitado a $5 \%$ e o intervalo de confiança para o "odds ratio" foi calculado para 95\%. A análise estatística foi 
realizada em programa SPSS, versão 9.0 (SPSS Incorporation, Chicago, II., U.S.A., 1999). 
RESULTADOS 
5 RESULTADOS

5.1 Grupos estudados: pacientes com DDC e grupo controle

Antecedentes clínicos e resultado dos estudos com os pacientes e com o grupo controle (Tabela 8) (Tabela 9): 


\section{Tabela 8 - Estudo dos controles para inclusão no Protocolo de Estudo (CAPPesq - No 222/03)}

\begin{tabular}{|c|c|c|c|c|c|c|}
\hline Paciente & $\mathbf{I}$ & $\mathbf{S}$ & $\begin{array}{c}\text { Laudo } \\
\text { Colonoscopia }\end{array}$ & $\begin{array}{c}\text { Doenças } \\
\text { Associadas }\end{array}$ & $\begin{array}{c}\text { Cirurgia } \\
\text { prévia }\end{array}$ & Mutação \\
\hline R52 & 59 & M & Pólipos Colônicos & $\begin{array}{l}\text { Tabagismo } \\
\text { Etilismo }\end{array}$ & Não & Ausente \\
\hline R55 & 61 & $\mathrm{~F}$ & Cólon Normal & - & $\mathrm{COL}^{* *}$ & Ausente \\
\hline R56 & 51 & $M$ & Cólon Normal & Tabagismo & Não & Ausente \\
\hline R58 & 37 & $\mathrm{M}$ & Cólon Normal & - & Não & Ausente \\
\hline R59 & 32 & $\mathrm{M}$ & RCUI * & Tabagismo & Não & Ausente \\
\hline $\mathrm{R} 60$ & 27 & $\mathrm{~F}$ & RCUI & $\begin{array}{c}\text { Tabagismo } \\
\text { Hipotireoidismo }\end{array}$ & Não & Ausente \\
\hline R61 & 48 & $\mathrm{~F}$ & RCUI & - & Não & Ausente \\
\hline R63 & 23 & $\mathrm{~F}$ & Cólon Normal & Osteomalácia & Não & Ausente \\
\hline R64 & 47 & $\mathrm{~F}$ & RCUI & - & Não & Ausente \\
\hline R65 & 61 & $\mathrm{~F}$ & Cólon Normal & $\mathrm{OOF}^{* * *}$ & Não & Ausente \\
\hline R66 & 44 & $\mathrm{~F}$ & RCUI & Hemorróidas & Não & Ausente \\
\hline R67 & 56 & $\mathrm{~F}$ & Cólon Normal & Hemorróidas & Não & Ausente \\
\hline R68 & 60 & $\mathrm{~F}$ & Doença de Crohn & Tabagismo & Não & Ausente \\
\hline R69 & 39 & $\mathrm{~F}$ & Cólon Normal & Hemorróidas & Não & Ausente \\
\hline R70 & 38 & $\mathrm{~F}$ & Doença de Crohn & Tabagismo & $\mathrm{COL}$ & Ausente \\
\hline R72 & 38 & $\mathrm{~F}$ & RCUI & - & Não & Ausente \\
\hline R73 & 62 & $\mathrm{~F}$ & Cólon Normal & $\begin{array}{c}\text { Tabagismo } \\
\text { Hipotireoidismo }\end{array}$ & Não & Ausente \\
\hline $\mathrm{R} 74$ & 49 & $\mathrm{~F}$ & $\begin{array}{c}\text { Angiodisplasia } \\
\text { Pólipos no Transverso } \\
\text { Varizes no Reto }\end{array}$ & - & Não & Ausente \\
\hline R75 & 56 & $\mathrm{~F}$ & Pólipos Colônicos & - & Não & Ausente \\
\hline R76 & 41 & $\mathrm{~F}$ & Cólon Normal & - & Não & Ausente \\
\hline $\mathrm{R} 78$ & 54 & $\mathrm{~F}$ & Cólon Normal & $\begin{array}{l}\text { Hipertensão } \\
\text { Arterial }\end{array}$ & Não & Ausente \\
\hline $\mathrm{R} 79$ & 60 & M & RCUI & $\begin{array}{l}\text { Tabagismo } \\
\text { Etilismo }\end{array}$ & Não & Ausente \\
\hline R81 & 60 & $M$ & Cólon Normal & Tabagismo & Não & Ausente \\
\hline R82 & 31 & $\mathrm{M}$ & Cólon Normal & Tabagismo & Não & Ausente \\
\hline R83 & 50 & $\mathrm{~F}$ & Cólon Normal & $\begin{array}{l}\text { Hipertensão } \\
\text { Arterial }\end{array}$ & Não & Ausente \\
\hline R84 & 45 & $\mathrm{~F}$ & RCUI & - & Não & Ausente \\
\hline
\end{tabular}


Tabela 9 - Estudo dos pacientes com DDC para inclusão no Protocolo de Estudo (CAPPesq - No 222/03)

\begin{tabular}{|c|c|c|c|c|c|c|}
\hline Paciente & $\mathbf{I}$ & $\mathbf{S}$ & $\begin{array}{c}\text { Laudo } \\
\text { Colonoscopia }\end{array}$ & $\begin{array}{l}\text { Doenças } \\
\text { associadas }\end{array}$ & $\begin{array}{l}\text { Cirurgia } \\
\text { Prévia }\end{array}$ & Mutação \\
\hline R51 & 55 & M & DDC em Sigmóide & $\begin{array}{l}\text { Hipertensão } \\
\text { arterial }\end{array}$ & Não & Presente \\
\hline R53 & 55 & $\mathrm{~F}$ & DDC em Sigmóide & Varizes MMlls & $\mathrm{HIST}^{*}$ & Ausente \\
\hline R54 & 70 & $\mathrm{~F}$ & $\begin{array}{c}\text { DDC em Sigmóide } \\
\text { Espasticidade Colônica } \\
\text { Universal }\end{array}$ & $\begin{array}{l}\text { Hipertensão } \\
\text { arterial } \\
\text { Tabagismo }\end{array}$ & GAST $^{* *}$ & Presente \\
\hline R57 & 46 & $\mathrm{~F}$ & $\begin{array}{c}\text { DDC em Sigmóide e } \\
\text { Cólon Descendente } \\
\text { Espasticidade Colônica } \\
\text { Universal }\end{array}$ & Tabagismo & Não & Presente \\
\hline R62 & 53 & $\mathrm{~F}$ & DDC em Sigmóide & $\begin{array}{l}\text { Hemorroidas } \\
\text { Arritmia }\end{array}$ & Não & Ausente \\
\hline $\mathrm{R} 77$ & 57 & $\mathrm{~F}$ & $\begin{array}{l}\text { DDC Universal e Pólipo } \\
\text { Cólon Ascendente }\end{array}$ & $\begin{array}{l}\text { Hipertensão } \\
\text { arterial } \\
\text { Tabagismo } \\
\end{array}$ & Não & Presente \\
\hline R85 & 72 & $\mathrm{~F}$ & DDC Universal & - & Não & Ausente \\
\hline R86 & 77 & M & DDC Universal & Tabagismo & $\begin{array}{l}\mathrm{GAST}^{* *} \\
\mathrm{COL}^{* * *}\end{array}$ & Ausente \\
\hline R87 & 52 & M & $\begin{array}{l}\text { DDC em Sigmóide e } \\
\text { Cólon Descendente }\end{array}$ & $\begin{array}{l}\text { Hipertensão } \\
\text { arterial } \\
\text { Tabagismo } \\
\text { e Angina } \\
\end{array}$ & Não & Ausente \\
\hline R88 & 71 & $\mathrm{~F}$ & $\begin{array}{c}\text { DDC em Sigmóide e } \\
\text { Cólon Descendente } \\
\text { Espasticidade Colônica } \\
\text { Universal }\end{array}$ & $\begin{array}{l}\text { Hipertensão } \\
\text { arterial }\end{array}$ & Não & Ausente \\
\hline R89 & 67 & M & DDC Universal & $\begin{array}{l}\text { Tabagismo e } \\
\text { Etilismo }\end{array}$ & Não & Ausente \\
\hline $\mathrm{R} 90$ & 42 & M & $\begin{array}{l}\text { DDC em Sigmóide e } \\
\text { Cólon Descendente }\end{array}$ & - & Não & Presente \\
\hline R91 & 47 & $M$ & DDC Universal & - & Não & Ausente \\
\hline R92 & 66 & $\mathrm{~F}$ & DDC em Sigmóide & $\begin{array}{l}\text { Hipertensão } \\
\text { arterial }\end{array}$ & Não & Ausente \\
\hline
\end{tabular}

${ }^{*}$ HIST $=$ Histerectomia ${ }^{* *}$ GAST = Gastrectomia ${ }^{* * *}$ COL = Colecistectomia 


\subsection{Análise do polimorfismo do exon 20 do gene da elastina pelo SSCP}

Os 40 indivíduos adultos foram analisados para a verificação de mutações no exon 20 do gene da ELN. O grupo de pacientes com DDC foi confrontado com os controles. O DNA genômico destes pacientes foi amplificado para o exon 20 do gene da ELN utilizando-se primers específicos, conforme sequências descritas por TASSABEHJI et al. (1997).

A análise dos géis de poliacrilamida revelou a possibilidade da presença de mutações no exon em questão, pelo fato de terem sido observadas distribuição de bandas diferentes entre o grupo de pacientes e os indivíduos controles (Figura 8).

Figura 8 - Eletroforese de poliacrilamida para análise do polimorfismo conformacional de fita simples do exon 20 do gene da elastina. A seta indica o sítio provável de mutação.

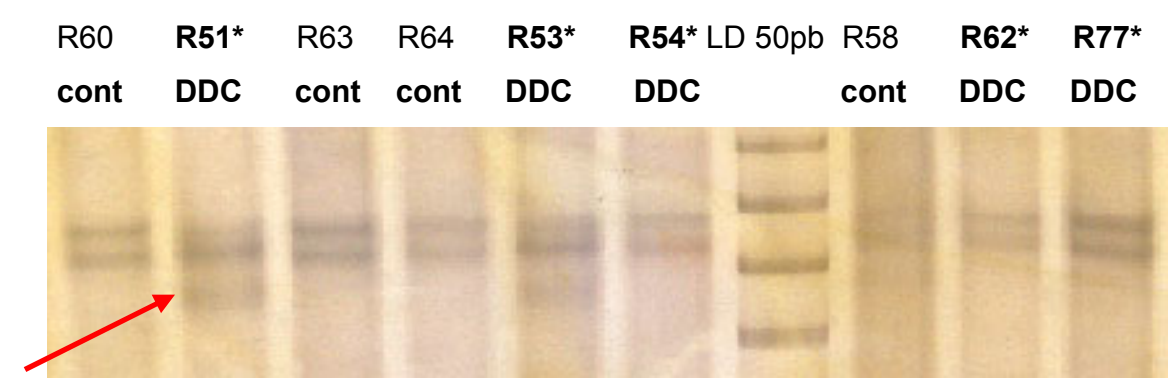

Este resultado corresponde à ocorrência de polimorfismo conformacional do exon 20 do gene da ELN nos indivíduos estudados. Diante deste fato, para confirmação da ocorrência de mutações realizou-se o sequenciamento do exon 20 do gene da ELN. 
5.3 Análise do sequenciamento do exon 20 do gene da elastina

O sequenciamento do produto de amplificação do exon 20 do gene da ELN revelou a presença de um tipo de mutação neste exon. A mutação observada está representada por uma troca simples no códon 422 AGT, onde a primeira base A foi trocada pela base G, ficando o códon GGT (Figura 9).

Figura 9 - Resultado do sequenciamento do produto de amplificação do exon 20 do gene da elastina. Seta apontando o local da mutação (simples troca AGT $\rightarrow$ GGT) no códon 422.

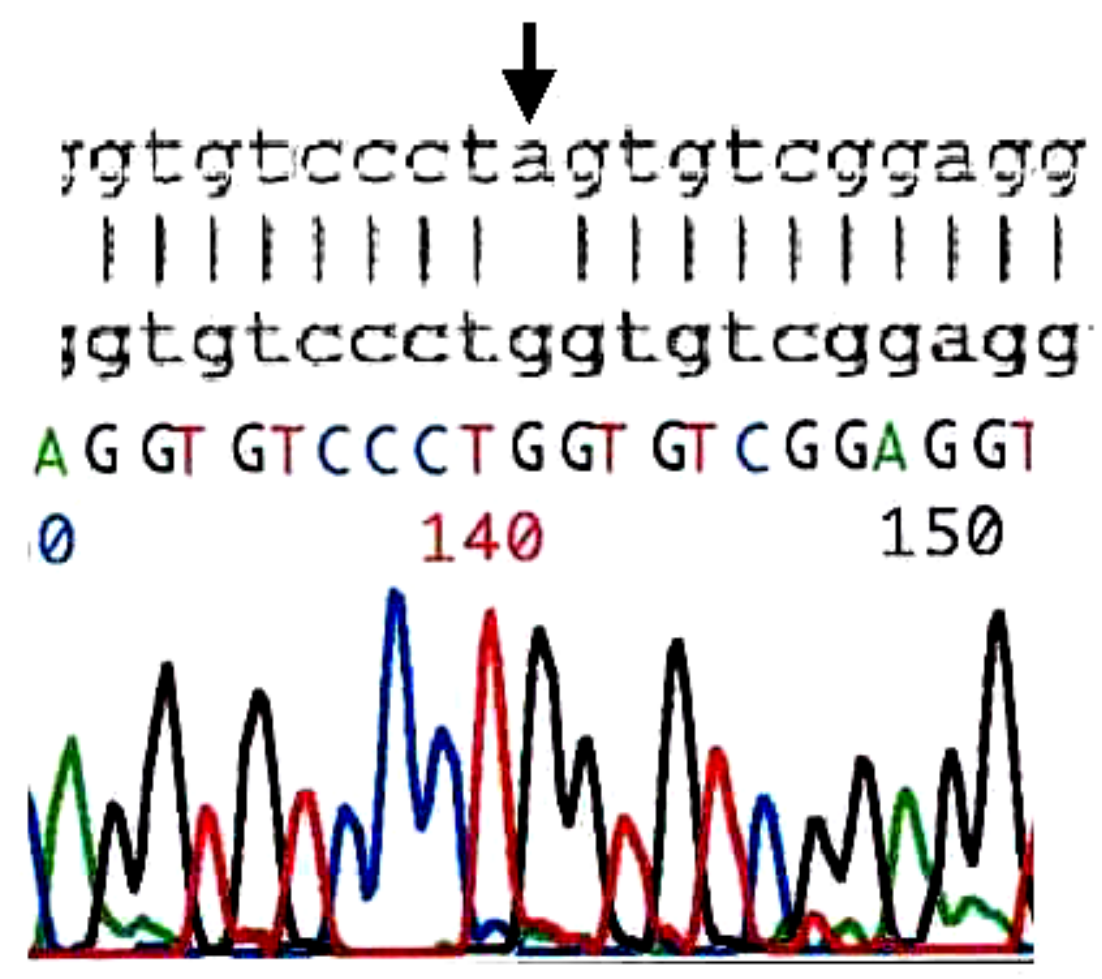

A análise da frequência desta mutação revelou que esta troca no códon 422 AGT $\rightarrow$ GGT, estava presente apenas nos indivíduos com DDC. 
Esta mudança estava presente em 05 de 14 pacientes $(35,7 \%)$ com DDC.

A análise estatística pelo Teste Exato de Fisher revelou que a proporção desta observação em diferentes categorias é significativamente diferente em relação às proporções esperadas de ocorrências aleatórias (Tabela 10) (Tabela 11) (Tabela 12).

O Teste Exato de Fisher mostrou associação estatisticamente significativa entre a ocorrência desta mutação e a DDC.

Tabela 10 - Análise Estatística Comparativa dos grupos controle e portadores de DDC, com ou sem mutação.

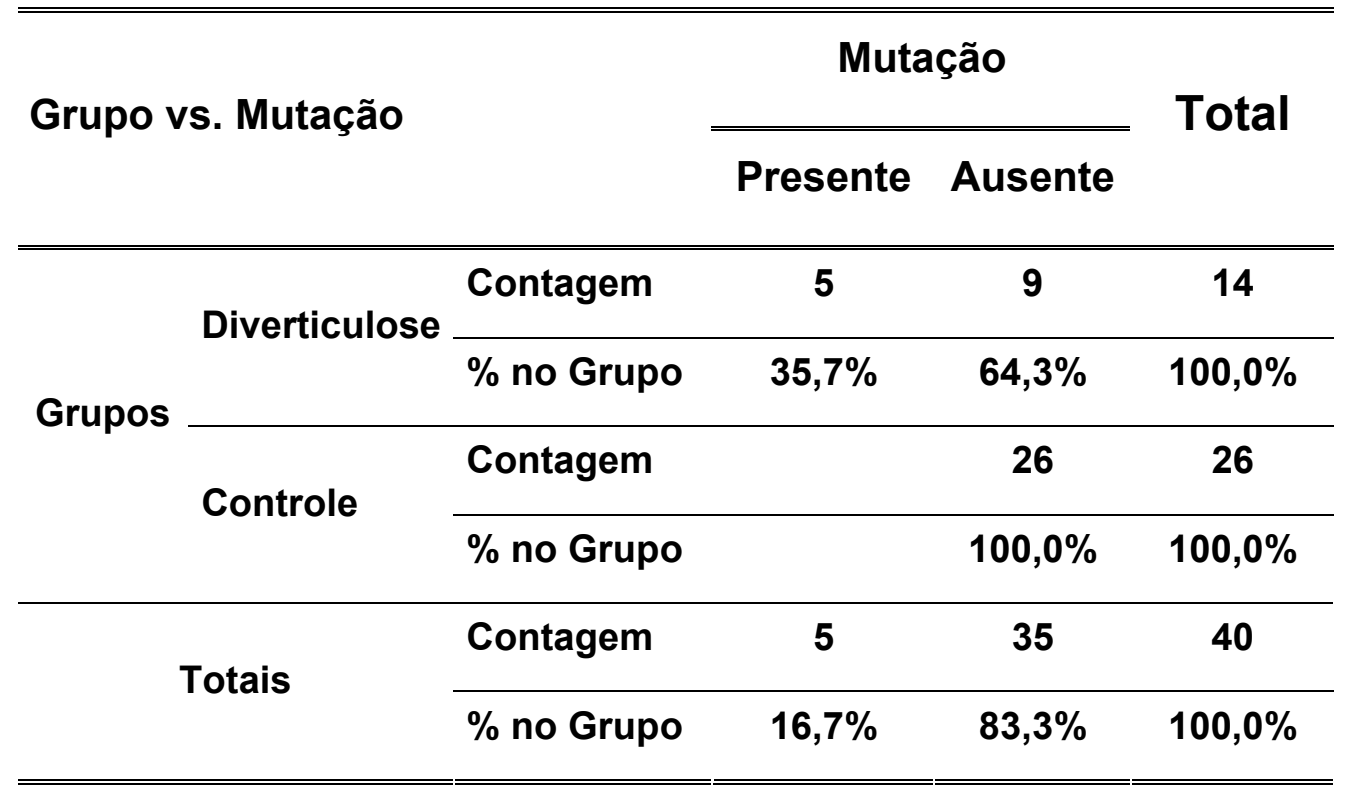


Tabela 11 - Análise Estatística pelo Teste Exato de Fisher para todos os grupos estudados (A, B e C) em relação ao códon 422 $(A G T \rightarrow G G T)$ no exon 20 do gene da elastina.

\begin{tabular}{lccc}
\hline \hline MUTAÇÃO & GRUPO A* & $\begin{array}{c}\text { GRUPOS } \\
B^{* *} / C^{* * *}\end{array}$ & \multirow{2}{*}{ TOTAIS } \\
\hline \hline Códon 422 & Controle & DDC & \\
\hline Presença de Mutação & 0 & $5^{* *}$ & 5 \\
\hline Ausência de Mutação & $26^{*}$ & $9^{* * *}$ & 35 \\
\hline TOTAIS & 26 & 14 & 40 \\
\hline \hline
\end{tabular}

* A - Grupo Controle

** B - Pacientes DDC com presença de mutação

*** C - Pacientes DDC com ausência de mutação

$\boldsymbol{P}<0,003$

Tabela 12 - Risco Relativo dos indivíduos que apresentam mutação no códon 422 de apresentarem DDC, considerando todos os grupos estudados (A, B e C).

\begin{tabular}{|c|c|c|c|}
\hline & \multirow{2}{*}{ VALOR } & \multicolumn{2}{|c|}{$95 \%$ de Intervalo de Confiança } \\
\hline & & Inferior & Superior \\
\hline Presença de DDC & 3,89 & 2,21 & 6,83 \\
\hline
\end{tabular}

Teste Exato de Fisher $p=0,003$ (portanto $p<0,003$ ).

Risco Relativo: $R R=3,89$ intervalo de confiança 95\% $(2,21: 6,89)$.

O risco relativo calculado foi de 3,89 (intervalo de confiança de 95\%:

2,21-6,83) vezes maior para indivíduos que apresentavam esta mutação pontual no códon 422 em relação aos indivíduos controles. 
DISCUSSÃO 


\section{DISCUSSÃO}

Partindo das evidências anteriormente apresentadas é possível pensar que a rigidez e a segmentação da parede colônica, provavelmente relacionada ao hábito prolongado e crônico de uma dieta pobre em fibras e resultante de uma alta pressão intraluminal, assim como o envelhecimento e possíveis alterações na matriz extracelular, conduzem à formação dos divertículos colônicos. Este parece ser o caso pelo menos no tipo de diverticulose clássica do lado esquerdo, com associação do espessamento muscular, mais comumente observada nos países ocidentais.

As pesquisas sobre o envolvimento do tecido conjuntivo têm sido direcionadas para as alterações na síntese, deposição ou composição do colágeno nos seus diferentes tipos e em tecidos de diferentes órgãos e estruturas, correlacionando suas alterações com o envelhecimento.

Os componentes da matriz extracelular, como o colágeno, a elastina e as glicoproteínas, parecem ser importantes na manutenção da firmeza e integridade da parede colônica (THOMSON et al., 1986). É possível que a degradação do colágeno maduro, seguida da síntese de novo colágeno, leve à fraqueza da parede colônica. 
WHITEWAY e MORSON (1985) demostraram que o espessamento das musculaturas longitudinal e circular observado na DDC não era devido à hiperplasia ou hipertrofia, aparentando estar relacionado ao estado de contratilidade da parede colônica. $\mathrm{O}$ aumento da quantidade das fibras elásticas ou elastose foi observada unicamente na musculatura longitudinal. Foi sugerido que a elastose da musculatura longitudinal era responsável pela contração longitudinal, com consequente espessamento de ambas camadas musculares.

A proteína elastina (ELN) é um componente importante dos tendões, fáscias e ligamentos, pois confere distensibilidade reversível e resistência aos tecidos, permitindo que retornem à sua forma original quando submetidos a estresse mecânico. Várias doenças hereditárias e adquiridas decorrem de anomalias das fibras elásticas (ROSENBLOOM, 1984) (UITTO et al.,2001 ). Com relação a etiologia da DDC, pouco se sabe sobre o papel das fibras elásticas, mas os dados fisiopatológicos desta doença sugerem que alterações estruturais do tecido conjuntivo promovam o enfraquecimento da parede colônica, acarretando a formação de divertículos.

A elastina é sintetizada principalmente nos tecidos em desenvolvimento e não se sabe se o desarranjo estrutural das fibras elásticas observado em várias doenças e no envelhecimento é decorrente de alterações no processo de elastogênese ou do aumento da atividade elastolítica, pois após a destruição das fibras elásticas as células elastogênicas são frequentemente reativadas e começam a sintetizar alguns dos componentes das fibras elásticas, mas na maioria das vezes, o produto 
é aberrante e não cumpre com sua função normal no tecido (ROBB et al.,1999).

A idéia de que a DDC possa decorrer de alterações difusas do tecido conjuntivo encontra respaldo na observação de que tais condições, frequentemente, cursam em associação com outras afecções atribuídas ao comprometimento desse tecido, como varizes (ULMSTEN et al., 1987) e estrias cutâneas (SAYER et al., 1990).

O comprometimento do gene da ELN, localizado no braço longo do cromossomo 7, através de variados graus de mutação, tem sido demonstrado na gênese de várias afecções como a síndrome de Williams (deleção), EASV (deleção ou mutações pontuais do exon 21 ou 26) e a síndrome da cutis laxa (mutações pontuais do exon 30 ou 32).

No presente estudo, para testarmos a hipótese de que mutações pontuais no gene da ELN pudessem acarretar o enfraquecimento do tecido conjuntivo do cólon, estudamos o exon 20 do gene da ELN num grupo de 14 pacientes com diagnóstico colonoscópico de DDC, comparando-os com outro grupo de 26 controles sem a presença de DDC à colonoscopia. Foi demonstrada uma associação significativa desta mutação com o desenvolvimento da DDC e um risco relativo 3,89 vezes maior (intervalo de confiança de 95\%: 2,21-6,83) dos indivíduos com esta mutação desenvolverem DDC, quando comparados aos indivíduos que não apresentaram esta mutação.

A existência de outro trabalho sobre o tema é desconhecida e, sabendo-se que o gene da ELN é constituído de 34 exons (TASSABEHJI et 
al.,1997), a opção para a pesquisa poderia ter sido por qualquer um dos exons apontados, entretanto, a escolha pelo exon 20 não foi aleatória, mas pelas razões expostas a seguir:

1. O exon 20, assim como os exons $2,3,5,7,9,11,13,14,16,18,22,24$, 26, 28, 30, 32, 33 (TASSABEHJI et al., 1997), codifica propriedade hidrofóbica da elastina (SANDBERG et al., 1989), responsáveis pela função de distensibilidade reversível dos tecidos (ROSENBLOOM, 1984);

2. O produto final do gene da ELN é resultado do fenômeno de splicing alternativo, com correlação tecido-específica (VRHOVSKI e WEISS, 1998) (INDIK et al., 1989) (GROND-GINSBACH et al., 2000). O exon 20 do gene da ELN não sofre este tipo de fenômeno;

3. Foram descritas mutações pontuais nos códons 404 e 422 do exon 20 do gene da ELN em pacientes portadores de hérnia inguinal (YOO, 2003). A substituição de um aminoácido não polar por outro de carga neutra altera o domínio hidrofóbico e pode modificar a elasticidade da molécula tornando a proteína hidrofílica, o que favoreceria a ação das enzimas proteolíticas, contribuíndo dessa forma para o enfraquecimento tecidual e o consequente desenvolvimento de hérnia inguinal. Indivíduos com hérnia inguinal apresentam alterações estruturais e quantitativas de fibras elásticas na fáscia transversal (RODRIGUES JÚNIOR et al., 1990; QUINTAS et al., 2000).

4. Dois estudos independentes, não encontraram associação entre alelos polimórficos do códon 422 glicina/serina e a prevalência de defeitos cardiovasculares na síndrome de Williams (WANG et al., 1999). 
O estudo proposto pode ser metodologicamente definido como de "associação genética", no qual a pesquisa é orientada para determinar se há relação entre um "marcador genético", no presente caso algum padrão de mutação do exon 20 do gene da ELN, e a frequência ou variedade de um determinado fenótipo, na DDC; embora por vezes referido como um teste de tentativa e erro, esse tipo de investigação contribui para o entendimento de processos biológicos básicos e para a compreensão e tratamento da patologia humana (LOCKHART e WINZELER, 2000). Entretanto, é necessário pensar que outros mecanismos de regulação tecidual podem também estar envolvidos, independentes da ação do gene da ELN. Ou ainda, o mecanismo de regulação da atividade das metaloproteinases da matriz pode ser importante nesse processo, pois esta família de endopeptidases degrada todo tipo de matriz extracelular, tais como colágeno, elastina e glicoproteínas. Por serem secretadas por uma variedade de células, inclusive por macrófagos, células $T$ e miofibroblastos após a estimulação por ocitocinas, além de outros fatores dentre os quais é possível destacar a flora bacteriana que se apresenta alterada na dieta pobre em fibras.

LEUNG et al. (1976) demonstraram que a distensão repetida e intermitente in vitro pode resultar em aumento na síntese dos componentes do tecido conjuntivo. É possível levantar a hipótese de que uma carga fecal reduzida como resultado da dieta Ocidental, distenderia o cólon intermitentemente, iniciando um processo de deposição de tecido conjuntivo na parede colônica. Esta hipótese encontra apoio nos achados de 
espécimes ressecados, onde observaram fibras elásticas em vários estágios de maturação, sugerindo uma síntese contínua de matriz extracelular (WHITEWAY e MORSON, 1985a). De forma interessante, esse argumento pode ter validade porque o padrão de elastose ou de deposição de fibras elásticas presente na DDC é semelhante ao encontrado na hipertensão pulmonar, na qual a artéria pulmonar deve suportar intermitentemente aumentos da pressão.

Por outro lado, SMITH (1986) sugere que uma alteração da dieta tem efeito sobre as propriedades físicas do cólon levando à elastogênese. O cólon apresenta uma propriedade mecânica chamada pré-tensão (WAINWRIGHT, 1986). Esse fenômeno ocorre em muitos tecidos vivos que são mantidos sobre diversas condições de alongamento e pode ser demonstrada pelo encurtamento do cólon ou dos vasos sanguíneos quando são extirpados. Essa propriedade física permite a manutenção da forma e assim permite a expansão dos tecidos em uma direção sem alterar o comprimento da outra. SMITH (1986) sugeriu que o aumento da elastina nas tênias pode ser uma compensação pela redução da pré-tensão, secundária a uma dieta pobre em fibras. As ondas lentas ao longo do cólon são geradas por esta parte da parede e sua frequência está alterada em alguns pacientes com DDC. Se essas duas mudanças estão relacionadas e se as alterações na frequência das ondas lentas são mecanicamente significativas, permanecem sem esclarecimento.

No cólon normal o colágeno e a elastina formam uma malha de espaços abertos distribuídas ao longo da parede, representando os 
componentes mais importantes para suportar a tensão da pressão intracolônica. Indiferentemente da presença ou não da pressão intracolônica, a debilidade estrutural do tecido conjuntivo faria o cólon mais suscetível à herniação da mucosa através da parede. Em estudos in vivo PARKS e CONNELL (1969) e em experiências adicionais in vivo de SMITH et al. (1976), mostraram um aumento na tendência desse processo estar presente no cólon diverticular, indicando uma redução na integridade estrutural da parede intestinal. Não está claro se essas alterações são localizadas ou afetam a totalidade do cólon. Como PARKS (1968), SMITH e SHEPHERDS (1976) encontraram que essas alterações persistiam na parte não afetada do cólon após a ressecção e concluíram que pode existir uma redução disseminada da integridade estrutural, o que levaria a uma predisposição geral para a formação de divertículos.

A evidência epidemiológica demonstra um aumento na incidência de DDC com o aumento da idade; talvez o achado mais importante a esse respeito é a redução da resistência à tração da parede do cólon com o aumento da idade (DRUMMOND, 1916) (SLACK, 1960). O mecanismo subjacente ainda permanece incerto. O maior componente estrutural da submucosa é o colágeno (LORD et al., 1977), cujas fibras estão dispostas numa rede descontinuada que, junto com as fibras elásticas, fornecem dureza e expansibilidade e permitem a manutenção da forma (WHITEWAY e MORSON, 1985b) (WATTERS et al., 1985). As fibrilas de colágeno apresentam um aumento das ligações cruzadas (ROBINS et al., 1973; WESS et al., 1995) com a idade e, no cólon esquerdo, tornam-se menores, 
mais numerosas e mais intimamente reunidas; essa tendência é mais pronunciada na DDC (THOMSON et al., 1987). PACE (1966) demonstrou que a camada de tecido de colágeno entre as camadas musculares longitudinal e circular do cólon normal fica reduzida com o aumento da idade.

O conteúdo de elastina aumenta ao longo da vida em todas as camadas do cólon (SMITH, 1986), embora sua deposição predomine nas tênias de pacientes com DDC e suas fibras se tornam mais curtas, mais grossas e mais onduladas, o que pode facilitar o aumento da distensibilidade do cólon diverticular (PARKS e CONNELL, 1969) (SMITH e SHEPHERD, 1976). Há também um firme aumento na espessura da parede do intestino com a idade, afetando ambas camadas musculares, longitudinal e circular. Considerações sobre esses achados, em relação a estudos mecânicos que indicam uma redução da resistência à tração (IWASAKI e OKATOMO, 1953) (WATTERS et al., 1985), sugerem que o aumento da espessura muscular com a idade, não é uma compensação pela redução qualitativa da integridade mecânica da parede colônica.

Qual seria a repercussão da mutação do gene da elastina na DDC ? Reportando-se ao gene da ELN, constata-se que o exon 20 está relacionado ao domínio hidrofóbico da mesma. Esta mutação codifica um aminoácido diferente do original, o códon 422 que codifica serina (AGT) passa a codificar a glicina (GGT). A substituição de um aminoácido não polar por outro de carga neutra altera o domínio hidrofóbico e pode alterar a elasticidade da molécula bem como sua resistência à proteólise, sendo 
possível que esta mutação resulte em alterações na função da proteína ELN, tornando o polipepitídeo mutante mais susceptível à degradação proteolítica. Os efeitos das mutações do gene da ELN são tecido-específica pois dependem das diferenças na biosíntese da elastina, na interação célulamatriz e na fisiologia tecidual (MILEWICZ et al., 1996). Assim, é correto supor que a mutação no códon 422 do gene da ELN poderia explicar em parte a etiopatogenia da DDC.

A favor desta hipótese existem diversos estudos demonstrando que mutações ou deleções do gene da ELN são responsáveis pelo surgimento de doenças que afetam o tecido conjuntivo, promovendo alterações disfuncionais em órgãos dependentes de elasticidade. Indivíduos com síndrome de Williams (SW), causada por deleção hemizigótica no cromossomo 7q11.23, que alberga o gene da ELN, apresentam alteração da elasticidade e resistência dos tecidos (DRIDI et al., 1999).

A síndrome de cutis laxa congênita caracteriza-se por grande lassidão da pele e comprometimento pulmonar e cardiovascular, decorrente de formação defeituosa de fibras elásticas (ZHANG et al., 1999).

$\mathrm{Na}$ EASV ocorrem grandes deleções do gene da ELN, que se expressa com alterações cardíacas e estenose de múltiplas artérias (EWART et al., 1994; OLSON et al., 1995).

Como explicar o fato que apenas alguns tecidos ou melhor, tecidos específicos apresentem alterações estruturais dependentes de mutações do gene da ELN? Neste entendimento temos BASHIR et al. (1989), que revelaram que o gene da ELN tem sítios múltiplos de iniciação que sugerem 
a complexidade do controle da expressão. Desta forma, a expressão da ELN é regulada tanto pelo tipo de tecido, período de desenvolvimento, bem como pelo nível de mRNA da elastina (DAVIDSON e GIRO, 1986). Os mecanismos que regulam a expressão do gene da ELN nos fibroblastos não estão completamente definidos, tanto os mecanismos transcricionais e póstranscricionais parecem estar envolvidos. Os efeitos de vários peptídeos, como os fatores de crescimento, foram estudados em relação à expressão do gene da ELN. A interleucina -1 e o fator de necrose tumoral alfa (TNF- $\alpha$ ) parecem diminuir a transcrição em fibroblastos da derme humana e células de músculo liso de vasos de rato (BERK et al., 1991) (KAHARI et al., 1992). O fator de crescimento tumoral beta (TGF- $\beta$ ) aumenta a produção de elastina em cultura de fibroblastos de pulmão. O TGF- $\beta 1$ exógeno aumenta a meia-vida, ou a estabilidade, do mRNA da tropoelastina e não altera a transcrição do gene da ELN. Verificou-se que a quantidade de TGF- $\beta$ s no período pós-natal é de 4 a 5 vezes maior do que na idade adulta. A existência de diferenças de quantidades de TGF- $\beta$ s biologicamente ativos relacionada à idade pode explicar a diferença na estabilidade do mRNA de tropoelastina (MCGOWAN et al., 1997).

A mutação germinativa é aquela que existe desde o nascimento e pode ser identificada através do DNA do sangue periférico, já a mutação somática é identificada somente nos tecidos, como as provocadas por radiações.

O conceito de polimorfismo ou variante alélica se faz presente quando uma mutação atinge mais de $2 \%$ da população. Como o estudo de 52 alelos 
do grupo controle não identificou a mutação, fica sugerindo que não se trata de um polimorfismo e sim de uma mutação que pode ser uma das causas da DDC.

A troca de serina (AGT) por glicina (GGT) é uma mutação não conservativa (LEWIN, 1997), sendo possível que desencadeie uma elastinopatia. Se esta mutação realmente for a causadora do fenótipo, o portador da mutação terá um risco 3,89 vezes maior de desenvolver DDC.

Além de estudos de outras alterações genéticas da DDC, as pesquisas devem seguir na busca dos fatores envolvidos na modulação da transcrição da expressão do gene da ELN, quando deverá surgir a possibilidade da descoberta de agentes farmacológicos, como os retinóides (UITTO et al., 2001) e corticóides (MECHAM et al., 1984) ou por moléculas efetoras imunológicas como as citocinas (GIRO et al., 1988), para serem empregados como alternativas terapêuticas ou preventivas das doenças que envolvem o sistema de fibras elásticas. 
Figura 10 - Diagrama mostrando o conceito tradicional do mecanismo envolvido na diverticulose colônica. $O$ envelhecimento estaria associado com 0 enfraquecimento da parede colônica. A dieta pobre em fibras pode levar à diminuição da quantidade de fezes, resultando na segmentação colônica. A pressão intraluminal tende a ser alta no cólon segmentado e causa a herniação da mucosa e submucosa através da camada muscular enfraquecida, desenvolvendo em consequência a diverticulose colônica.

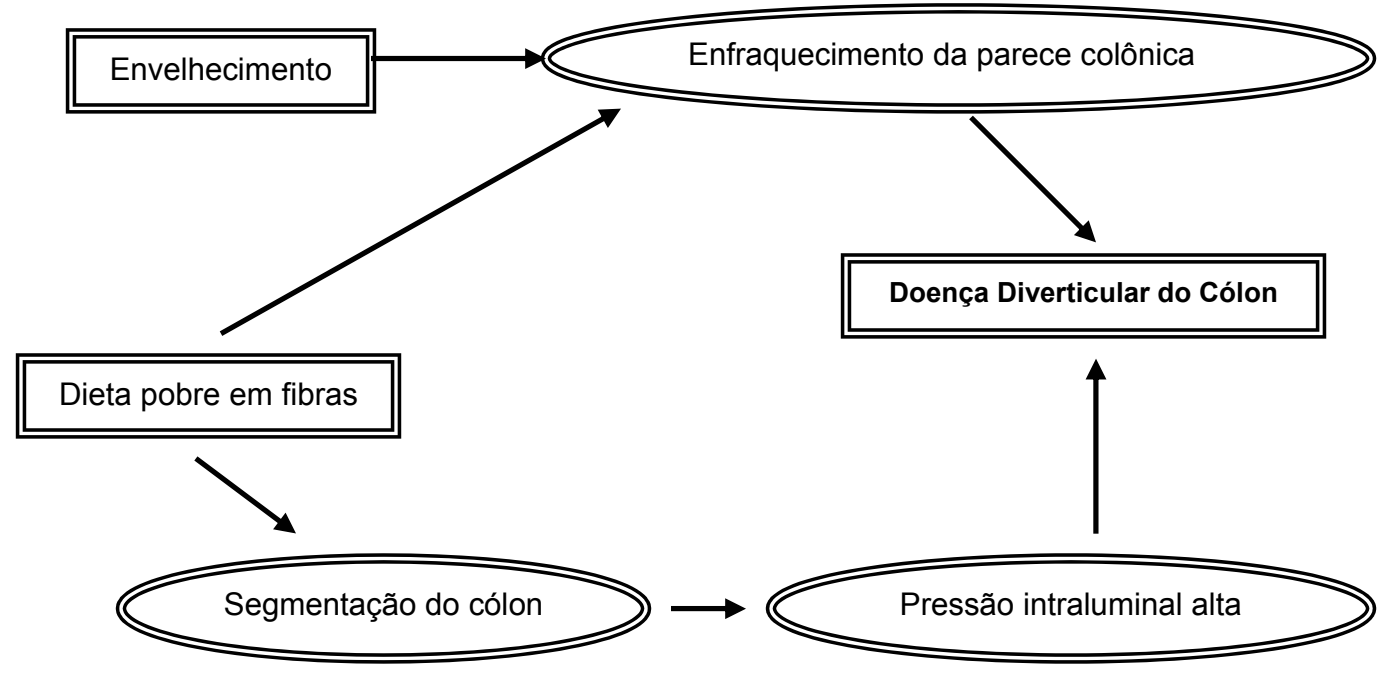


Figura 11 - Diagrama apresentando os conceitos atual e futuro da patofisiologia da Diverticulose Colônica. $O$ hábito prolongado de dieta pobre em fibras leva à hipertrofia da musculatura do cólon e a sua segmentação, fatos relacionados entre si. Esses fenômenos podem ser mediados por alteração da matriz extracelular e pela atividade do óxido nítrico. Os fatores genéticos e étnicos são importantes em relação ao local de predominância dos divertículos e na sua gênese. MMP, matriz de metaloproteinase; AGCC, ácidos graxos de cadeia curta.

Alteração da matriz extracelular; elastose, aumento do acoplamento transversal do colágeno; degeneração e regeneração do colágeno?; AGCC?; alteração da flora bacteriana luminal?

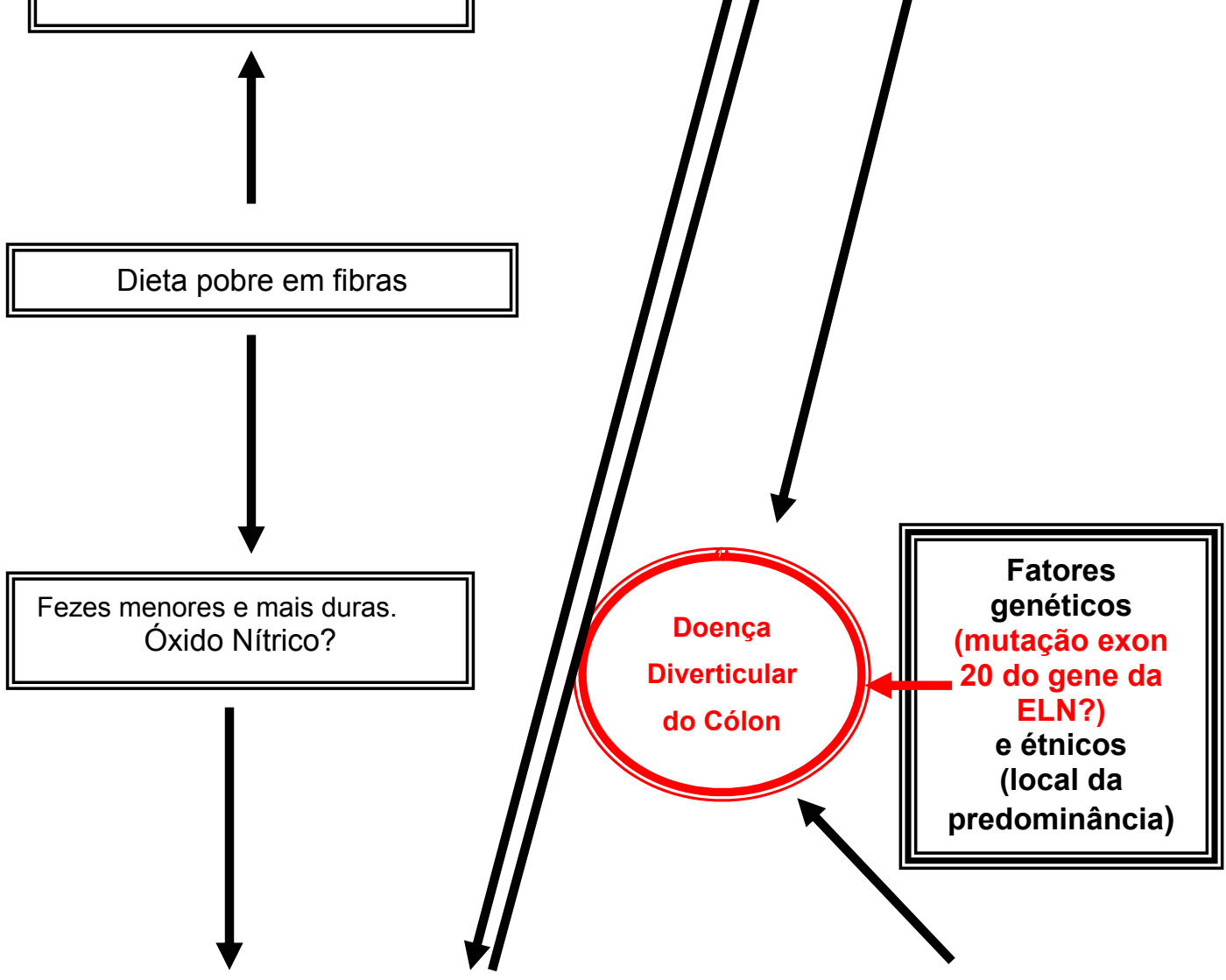


CONCLUSÕES 


\section{$7 \quad$ Conclusões}

Foi identificada a substituição de A (adenina) por G (guanina) no codon 422, localizado no exon 20 do gene da ELN, substituindo uma serina (AGT) por glicina (GGT), em 5 dos 14 portadores de DDC.

A substituição de uma serina por glicina no códon 422 do gene da ELN não foi identificada em nenhum dos 52 alelos de indivíduos sem DDC.

A mutação pode ser responsável pela etiologia da DDC, mas há necessidade de estudos da expressão da proteína mutada nos tecidos para avaliar a participação da mutação sobre o fenótipo. 
ALMY, T. P.; HOWELL, D. A. Diverticular disease of the colon. N. Engl. J. Med., v.302, p.324-31, 1980.

ARFWIDSSON, S. Pathogenesis of multiple diverticula of the sigmoid colon in diverticular discase. Acta Chir. Scand., v.342, Supplement, p.5-68, 1964.

ATTISHA, R. P.; SMITH, A. N. Pressure activity of the colon and rectun in diverticular discase before and after sigmoid myotomy. Acta Chir. Scand., p.342, 1964. Suplement.

AVERBACH, M.; D'ASSUNÇÃO, M. A.; BARROS, M. S .V; RIBEIRO, P. C.; HASHIBA, K. Colonoscopia: experiência de um hospital geral. Arq. Gastroenterol., v.28, p.52-4, 1991

BARROS, M. S. V.; RODRIGUES, C. J.; RODRIGUES, N. R.; OLIVEIRA, R. P.; BARROS, T. E. P.; RODRIGUES JUNIOR, A. J. Aging of the elastic and collagen fibers in the human cervical interspinous ligaments. Spine, v.2, p.57-62, 2002 .

BARROS, M. S. V. Estudo comparativo entre o sistema de fibras elásticas da camada muscular do cólon humano normal e do portador de moléstia diverticular adquirida. São Paulo, 1999, 91p. Tese (Doutorado) - Faculdade de Medicina, Universidade de São Paulo. 
BASHIR, M. M.; INDIK, Z.; YEH, H.; ORNSTEIN-GOLDSTEIN, N.; ROSENBLOOM, J. C.; ABRAMS, W.; FAZIO, M.; UITTO, J.; ROSENBLOOM, J. Characterization of the complete human elastin gene. J. Biol. Chem. v.264, p.8887-91, 1989.

BENGMARK, S. Ecological control of gastrointestinal tract. The role of probiotic flora. Gut, v.42, p.2-7, 1996.

BERK, J. L.; FRANZBLAU, C.; GOLDSTEIN, R. H. Recombinant interleukin1B inhibits elastin formation by a neonatal rat lung fibroblast subtype. J. Biol. Chem., v.266, p.3192-97, 1991.

BINQGLEY, L. J.; IUNG, E. Colonic diverticular disease: its spectrum in a community hospital. Post. Med., v.81, p.79-84, 1987.

BISACCIA, F.; CASTIGLIONE MORELLI, M.A.; SPISANI, S. et al. The amino acid sequence coded by the rarely expressed exon 26 A of human elastin contains a stable $\beta$-turn with chemotactic activity for monocytes. Biochemistry, v.37, p.11128-35, 1998.

BODE, M. K.; KARTTUNEN, T. J.; MÄKELÄ, J.; RISTELI, L.; RISTELI, J. Type I and III collagens in human colon cancer and diverticulosis. Scand. J. Gatroenterol., v.35, p.747-52, 2000. 
BOILEAU, C.; COLLOD, G.; BONNET, D. Contribution of genetics to pathogenicity and diagnosis of Marfan syndrome. Arch. Mal Coeur Vaiss, v.90, Suppl 12, p.1707-12, 1997.

BRAVERMAN, J. M.; FONFERKO, E. Studies in cutaneous ageing: the elastin fiber network. J. Invest. Dermatol., v. 78, p.434-43, 1982.

CASTRO, L. P; COELHO, L. G. V.; Doença diverticular dos cólons. In: Gastroenterologia Vol. 2. Ed. MEDSI, Rio de Janeiro, 2004.

CELIO, A. Zür pathologie der chronischer stenoisiereden diverticulitis coli. Helv. Chir. Acta, v.19, p.93, 1952.

CHIFFLET, A. Complicaciones de la colopatia diverticular. In: CONGRESO LATINO-AMERICANO DE PROCTOLOGIA, 2., Montevideo, 1963. Anales, Montevideo,1963. p.39-50.

CLOAREC, D.; LE BODIC, L.. Diverticulose colique: épidémiologie, physiopathologie, diagnostic, évolution, traitement. Rev. Prat., v.42, p.23326, 1992.

COOPER, G. M. A célula, uma abordagem molecular. 2.ed. Porto Alegre, Artmed, 2001. 
COOPER, D. N. Human gene mutation in pathology and evolution. J. Inher. Meta. Diseas., v.25, p.157-82, 2002

COTTA-PEREIRA, G.; RODRIGO, F.; BITTENCOURT-SAMPAIO, $S$. Oxytalan, elaunin and elastic fibers in the human skin. J. Invest. Dermatol., v.66, p.143-8, 1976.

COTTA-PEREIRA, G.; RODRIGO, F. G.; DAVID FERREIRA, J. F. The use of tannic acid-glutaraldehyde in the study of elastic and elastic-related fibers. Stain Technol., v.5 1, p.7-11, 1976.

CRUVEILHIER, J. Traité d' Anatomie Pathologique Générale, v.1. Paris, Bailliere, 1849.

DEBELLE, L.; TAMBURRO, A. M. Elastin: molecular description and function. The International Journal of Biochemistry \& Cell Biology, v.31, p.261-272, 1999.

DANIELSEN, L.; KOBAYASI, T. Internal elastic lamina of gastric arterires in pseudoxanthoma elasticum. Ultrastructural studies. Acta Pathol. Microbiol. Scand., v.80, p.697-704, 1972. 
DAVIDSON, J. M.; GIRO, M. G. Control of elastin synthesis: molecular and cellular aspects. In Regulation of Matrix Accumulation, p.178-216, Mecham, R. P. Editor, Academic Press. New York 1986.

DJAVAN, B; LIN, V.; KAPLAN, E. P.; RICHIER, J. C.; SHARIAT, S.; MARBERGER, M.; McCONNELL, J. D. Decreased elastin gene expression in noncompliant human bladder tissue: a competitive reverse transcriptasepolymerase chain reaction analysis. J. Urol., v.160, p.1658-62, 1998.

DRIDI, B. S.; GHOMRASSENI, S.; ORNSTEIN-GOLDSTEIN, N.; INDIK, Z. K.; YOON, K.; MAY, M.; OLIVER, L.; BOYD, C.; ROSENBLOOM, J. Chromosomal localization of the human elastin gene. Am. J. Hum. Genet., v.37, p.873-82, 1985.

DRUMMOND, $\mathrm{H}$. Sacculi of the large intestine, with special reference of their relations to the blood-vessels of the bowel wall. Br. J. Surg., v.4, p.407-13, 1916.

EASTWOOD, M. A.; SANDERSON, S.; POCOCK, S. J.; MITCHELL, W. D. Variation in the incidence of diverticular disease within the city of Edinburgh. Gut, v.18, p.571-4, 1977.

EASTWOOD, M. A.; WATTERS, D.A.K.; SMITH, A. N.. Diverticular disease: is it a motility disorder? Clin. Gastroenterol., v.11, p.545-61, 1982. 
EDWARDS, H. C. Diverticula of the collon and vermiform appendix. Lancet, v.1, p.221, 1934 .

EAWART, A. K.; MORRIS, C. A.; ATKINSON, D.; JIN, W.; STERNES, K.; SPALLONE, P.; STOCK, a. D.; LEPPERT, M.; KEATING, M. T. Hemizygosity at the elastin locus in a developmental disorder, Williams Syndrome. Nat. Genet., v.5, p.11-16, 1993.

EISENBERG, H.; HEISE, H. End-results in cance of the protate and urinary bladder, 1940 to 1959. Proc. Natl. Cancer Conf., v.5, p.331-40, 1964.

EMMANUEL, B. S.; CANNIZZARO, L.; ORNSTEIN-GOLDSTEIN, N.; INDIK, Z. K.; YOON, K; MAY, M.; OLIVER, L. et al. Chromosomal localization of the human elastin gene. Am. J. Hum. Genet., v.37, p.873-82, 1985.

EWART, A. K.; JIN, W.; ATKINSON, D.; MORRIS, C. A.; KEATING, M. T. Supravalvular aortic stenosis associated with a deletion disrupting the elastin gene. J. Clin. Invest., v.93, p.1071-77, 1994.

FAZIO, M. J.; KAHARI, V. M.; BASHIR, M. M.; SAITTA, B.; ROSENBLOOM, J.; UITTO, J. Regulation of elastin gene expression: evidence for functional promoter activity in the 5' flanking region of the human gene. J. Invest. Dermatol., v.94, p.191-6, 1990. 
FAZIO, M. J.; MATTEI, M. G.; PASSAGE, E.; CHU, M. L.; BLACK, D.; SOLOMON, E.; DAVIDSON, J. M.; UITTO, J. Human elastin gene: new evidence for localization to the long arm of chromosome 7. Am. J. Hum. Genet., v.48, p.696-703,1991.

FAZIO, M. J.; OLSEN, D. R.; KUIVANIEMI, H.; CHU, M. L.; DAVIDSON, J.; ROSENBLOOM, J.; UITTO, J.. Isolation and characterization of human elastin cDNAs, and age-associated variation in elastin gene expression in cultured skin fibroblasts. Lab. Invest., v.58, p.270-7, 1988.

FIFIELD, L. R. Diverticulitis. Lancet, v.i, p.277-81, 1927.

FINNEY, J. M. T. Diverticulitis and its surgical treatment. Proceedings, InterState Post-Graduate Medical Assembly of North America, v.55, p.57-65, 1928.

FISHER, N.; BERRY, C. S.; LEARN, T.; GREGORY, J. A.; HARD, J. Cereal dietary fiber consumption and diverticular disease: a lifespan study in rats. Am. J. Clin. Nutr., v.42, p.788-804, 1985.

FORD, M. J.; CAMILLERI, M.; WISTE, J. A. et al. Differences in colonic tone and phasic response to a meal in the transverse and sigmoid human colon. Gut, v.37, p.264-9, 1995. 
FOSTER, K.; FERRELL, R.; KING-UNDERWOOD, L.; POVEY, S.; ATTWOOD, J.; RENNICK, R.; HUMPHTIES, S. E.; HENNEY, A. M. Description of a dinucleotide repeat polymorphism in the human elastin gene and its use to confirm assignment of the gene to chromosome 7. Ann. Hum. Genet., v.57, p.87-96, 1993.

FULLMER, H.M.; LILLIE, R. D. The oxytalan fiber. A previosly undescribed connective tissue fiber. J. Histochem. Cytochem., v.6, p.425-30, 1958.

GAWLIK, Z. Morfological and morphochemical properties of elastic system in motor organ human. Folia Histochem. Cytochem., v.3, p.233-51, 1965.

GIRO, M. G.; DUVIC, M.; KENNEDY, R. Z.; SMITH, L. T.; DAVIDSON, J. M. Increased elastin production by Buschke-Ollendorf fibroblasts is further augmented by transforming growth factor beta. J. Cell. Biol., v.107, p.49A, 1988.

GOLIGHER, J. C. Cirurgia do ânus, reto e colo. 5. Ed., v.2, p.1172-207. São Paulo, Manole, 1990.

GRASER, E. Das falsche Darmdivertikel. Archivs Klinische Chirurgie, v.59, p.638-47, 1899. 
GROND-GINSBACH, C.; THOMAS-FELES, C.; WERNER, I.; WIGGER, F.; HAUSSER, I.; BRANDT, T. Mutations in tropoelastin gene (ELN) were not found in patients with spontaneous cervical artery dissection. Stroke, v.31, p.1935-8, 2000.

GOUKASSIAN, D.; GAD, F.; YAAR, M.; ELLER, M. S.; NEHAL, U. S.; GILCHREST, B. A. Mechanisms and implications of the age-associated decrease in DNA repair capacity. FASEB J., v.14, p.1325-34.

GUO-ZONG, P.; TONG-HUA, L.; MIN-ZHANG, C.; HSIAO-CHIEN, C. Diverticular disease of colon in China: a 60-year retrospective study. Chin. Med. J. , v.97, p.391-4, 1984.

GUTTMACHER, A. E.; COLLINS, F. S. Genomic medicine: genomic medicine - a primer. N. Eng. J. Med., v.347, p.1512-20, 2002.

HABR-GAMA, A.; BOCCHINI, S. Moléstia diverticular dos cólons. In: CORRÊA- NETTO, A. Clínica cirúrgica. São Paulo, Sarvier, 1988. Cap.52, p.523-38.

HINEK, A. Elastin receptor and tropoelastin chaperone. In: A. M. TAMBURRO (Ed.). Elastin and Elastic tissue, Armamento, Potenza, Italy, 1997, p.75-81 
HUGHES, L. E. Postmortem survey of diverticular disease of the colon. Part I. Diverticulosis and diverticulitis. Gut, v.10, p.336-44, 1969.

HUGHES, L. E. Postmortem survey of diverticular disease of the colon. Part II. The muscular abnormality of the sigmoid colon. Gut, v.10, p.344-51, 1969.

HUIZINGA, J. D.; WATERFALL, W. E.; STERN, H. S. Abnormal myogenic control activity in colonic smooth muscle from divertiular disease patients. Proceedings of the Smooth Muscle Function Symposium, Banff, Canada, 1986.

INDIK, Z.; YEH, H.; ORNSTEIN-GOLDSTEIN, N.; KUCICH, U.; ABRAMS, W.; ROSENBLOOM, J. C.; ROSENBLOOM, J. Structure of the elastin gene and alternative splicing of elastin mRNA: implication for human disease. Am. J. Med. Genet., v.34, p.81-90, 1989.

INDIK, Z.; YEH, H.; ORNSTEIN-GOLDSTEIN, N.; SHEPPARD, P.; ANDERson, N.; ROSENBlOOM, J. C.; PELTONEN, L.; ROSENBLOOM, J. Alternative splicing of human elastin mRNA indicated by sequence analysis of cloned genomic and complementary DNA. Proc. Natl. Acad. Sci., v.84, p.5680-84, 1987. 
IWASAKI, T.; OKATOMO, T. Study on the strength of human intestinal wall.

J. Kyoto Pref. Univ. Med., v.52, p. 673-702, 1953.

JACKSON, S. R.; AVERY, N. C.; TARLTON, J. F.; ECKFORD, S. D.; ABRAMS, P.; BAILEY, A. J. Changes in metabolism of collagen in genitourinary prolapse. Lancet, v.347, p.1658-61, 1996.

JACOB, M. P. L'invalidation du gène de la fibuline-5 induit une elastinopathie. Med./Scien., v.19, p.395-397, 2003.

JUNQUEIRA, L.C.; CARNEIRO, J. Histologia Básica. 4.ed. Guanabara Koogan, Rio de Janeiro 1979. p.83.

KAHARI, V. M.; CHEN, Y. Q.; BASHIR, M. M.; ROSENBLOOM, J.; UITTO, J. Tumor necrosis factor- $\alpha$ regulates human elastin gene expression. Evidence for the role of AP-1 in the supression of promoter activity. J. Biol. Chem., v.267, p.26134-41, 1992.

KARLINSKY, B.; SNIDER, G.; FRANZBLAU, C.; SNIDER, R.; REDI, J.; CATANFSE, A. In vitro effects of ciastase and collagenase on mechanical properties of hamster lungs. Am. Rev. Respir. Dis., v 3, p.769-77, 1976.

KEITH, A. Diverticula of the alimentary tract of congenital or obscure origin. Br. Med. Surg., v.i, p.376-80. 1910. 
KOWAL, R. C.; JOLSIN, J. M.; OLSON, E. N.; SCHULTZ, R. A. Assignement of fibulin-5 (FBN5) to human chromosome 14q31 by in situ hybridization and radiation hybrid mapping. Cytogenet. Cell Genet., v.87, p.2-3, 1999.

KUBO A.; ISHIWATA J.; MAEDA, Y. et al. Clinical studies on diverticular disease o the colon. Jpn. J. Med., v.22, p.185-9, 1983.

LEE, B.; GODFREY, M.; VITALE, E.; HORI, H.; MATTEI, M. G, SARFARAZI, M.; TSIPOURAS, P.; RAMIREZ, F.; HOLLISTER, D. W. Linkage of Marfan syndrome and a phenotypically related disorder to two different fibrillin genes. Nature, v.352, p.330-4, 1991.

LEUNG, D. Y. M.; GLAGOV, S.; MATHEWS, M. B. Cyclic stretching stimulates synthesis of matrix components of arterial smooth muscle cells in vitro. Science, v.191, p.475-7, 1976.

LEWIN, B. Genes, 6ed. Oxford University Press, New York, 1997.

LIPTAY, M. J.; PARKS, W. C.; MECHAM, R. P.; ROBY, J.; KAISER, L. R.; COOPER, J. D.; BTNEY, M. D. Neointimal macrophages colocalize with extracellular matrix gene expression in human atherosclerotic pulmonary arteries. J. Clin. Invest., v.91, p.588-94, 1993. 
LOCKHART, D. J.; WINZELER, E. A. Genomics, gene expression and DNA arrays. Nature, v.405, p.827-36, 2000.

LOEYS, B.; VAN MALDERGEM, L.; MORTIER, G.; COUCKE, P.; GERNIERS, S.; NAEYAERT, J. M.; DE PAEPE, A. Homozygocity for a missense mutation in fibulin-5 (FBLN5) results in a severe form of cutis laxa. Hum. Mol. Genet., v.11, p.2113-8, 2002.

LORD, M. G.; VALIES, P.; BROUGHTON, A. C. A morpholic study of the submucosa of the large instestine. Surg. Gynecol. Obstet., v.145, p. 55-60, 1977.

LOTZE, A.; KNIGHT G. R.; ANDERSON, K. D. et al. Surfactant (Beractant) therapy for infants with congenital diaphragmatic hernia on ECMO: Evidence of persistent surfactant deficiency. J. Pediatr. Surg., v.29, p.407-412, 1994.

MACDONALD, T. T.; PENDER, S. L. F. Proteolitic enzymes in inflammatory bowel disease. Inflammatory Bowel Disease, v.4, p.157-64, 1998.

MAGENIS, R. E.; MASLEN, C. L.; SMITH, L.; ALLEN, L.; SAKAI, L. Y. localization of the fibrillin (FBN) gene to chromosome 15, band q21.1 Genomics, v.11, p.346-51, 1991. 
MANOUSOS, O.; DAY, N. E.; TZONOU, A.; PAPADIMITRIOU, C.; KAPETANAKIS, A.; POLYCHRONOPOULOU-TRICHOPOULOU, A.; TRICHOPOULOS, D. Diet and other factors in the eatiology of diverticulosis: na epidemiological study in Greece. Gut, v.26, p.544-9, 1985.

MCGOWAN, S. E.; JACKSON, S. K.; OLSON, P. J.; PAREKH, T.; GOLD, L. I. Exogenous and endogenous TGF- $\beta$ influence elastin gene expression in cultured lung fibroblasts. Am. J. Resp. Cell Mol. Biol., v.17, p.25-35, 1997.

MECHAM, R. P.; MORRIS, S. L.; LEVY, B. D.; WRENN, D. S. lucocorticoids stimulate elastin production in differentiated bovine ligament fibroblasts but do not induce elastin synthesis in undiffirentiated cells. J. Biol. Chem., v.259, p.12414-8, 1984.

MENDELDORF, A. Thoughts on the epidemiology of diverticular disease. Clin. Gastroenterol., v.15, p.855-7,1986.

MENG, X.; LU, X.; LI, Z.; GREEN, E.; MASSA, H.; TRASK, B. J.; MORRIS, C. A.; KEATING, M. T. Complete physical map of the common deletion region in Williams syndrome and identification and characterization of three novel genes. Hum. Genet., v.103, p.590-9, 1998. 
MILEWICZ, D. M.; MICHAEL, K. B. S.; FISHER, N.; COSELLI, J. S.; MARKELLO, T.; BIDDINGER, A. M. S. Fibrillin-1 (FBN1) mutations in patients with thoracic aortic aneurysms. Circulation, v.94, p.2708-11, 1996.

MILLER, E. J.; MARTIN, G. R.; MECCA, C. H.; PIEZ, K. A. J. Biol. Chem., v.240, p.3623-27, 1965.

MIMURA, T.; EMANUEL, A.; KAMM, M. A. Pathophysiology of Diverticular Disease. Best Practice \& Research Clinical Gastroenterology, v.16, p.563-76, 2002.

MIURA, S.; KODAIRA, S.; AOKI, H. et al. Bilateral type diverticular disease of the colon. International Journal of Colorectal Diseases, v.11, p.71-5. 1996.

MORRIS, C. A.; DEMSEY, S. A.; LEONARD, C. O.; DILTS, C.; BLACKBURN, B. L.Natural history of Williams syndrome: phisical characteristics. J. Pediatr., v.113, p.318-26, 1988.

MORRIS, C. A. Genetic aspects of supravalvular stenosis. Curr. Opin. Cardiol.,v.13, p.214-9, 1998. 
MORTENSEN, P. B.; CLAUSEN, M. R. Short-chain fatty acids in the human colon: relation to gastrointestinal bleeding. Scand. J. Gastroenterol., v.216, p.132-48, Suppl.1996.

NAKADA, I.; UBUKATA, H.; GOTO, Y. et al. Diverticular disease of the colon at a general hospital in Japan. Diseases of the Colon and Rectum, v.38, p.755-9, 1995.

NICKERSON, E.; GREENBERG, F.; KEATING, M. T.; MCCASKILL, C.; SHAFFER, L. G. Deletions of the elastin gene at $7 q 11.23$ occur in approximately $90 \%$ of patiens with Williams syndrome. A. J. Hum. Genet., v.56, p.1156-61, 1995.

NOER, R. J. Hemorrhage as a complication of diverticulitis. Ann. Surg., v.14, p.674-85, 1955.

OLSON, T. M.; MICHELS, V. V.; URBAN, Z.; CSISZAR, K.; CHRISTIANO, A. M.; DRISCOLL. D. J.; FELTD, R. H.; BOYD, C. D.; THIBODEAU, S. N. A 30 $\mathrm{kb}$ deletion within the elastin gene results in familial supravalvular aortic stenosis. Hum. Mol. Genet., v.4, p.1677-9, 1995. 
ORITA, M.; IWAHANA, H.; KANAZAWA, H.; KAYASHI, K.; SEKIYA, T. Detection of polymorphisms of human DNA by gel electrophoresis as singlestrand conformation polymorphisms. Proc. Natl. Acad. Sci. U.S.A., v.86, p.2766-70, 1989.

PACE, J. L. A detailed study of the musculature of the human large instestine. PhD Thesis, London University, 1966.

PACE, J. L.; WILLIAMS, I. Organization of the muscular wall of the human colon. Gut., v.10, p.352-9,1969.

PAINTER, N. S.; TRUELOVE, S. C. Potential danger of morphine in acute diverticulitis of the colon. Br. Med. J., v.2, p.33,1963.

PAINTER, N. S.; TRUELOVE, S.C. The intraluminal pressure patterns in diverticulosis of the colon. Gut., v.5, p.201-13, 1964.

PAINTER, N. S.; TRUELOVE, S. C.; ARDRAN, G. M.; TUCKEY, M. Segmentation and the localization of intraluminal pressures in the human colon, with special reference to the pathogenesis of colonic diverticula. Gastroenterol., v.49, p.169-77, 1965, 
PAINTER, N. S.; BURKITT, D. P. Diverticular disease of the colon: a deficiency disease of Western civilization. Br. Med. J., v.2, p.450-4, 1971.

PAINTER, N. S.; BURKITT, D. P. Diverticular disease of the colon, a $20^{\text {th }}$ century problem. Clin. Gastroenterol., v.4, p.3-22, 1975.

PAINTER, N. S. The cause of diverticular disease of the colon, its symptoms and it complications. J. R. Coll. Surg. Edinb., v.30, p.1 18-23,1985.

PANIAGUA, R.; REGADERA, J.; NISTAL, M.; SANTAMARIA, L. Elastic fibers of the human ductus de ferrens. J. Anat., v.137, p.467-76, 1983

PARKS, T. G. Post-mortem studies on the colon with special reference to diverticular disease of the colon: a review of 521 cases. Proceedings of the Royal Society of Medicine, v.61, p.932-4, 1968.

PARKS, T. G.; CONNELL, A. M. Motility studies in diverticular disease of the colon. Gut, v.10, p.538-42, 1969.

PARKS, T.G. Reappraisal of clinical features of diverticular disease of the colon. Br Med. J., v.4, p.642-5, 1969. 
PARKS, T. G. Natural history of diverticular disease of the colon. Clin. Gastroenterol., v.4, p.53-69,1975.

PARTRIDGE, S. M.; ELSDEN, D. F.; THOMAS, J. Constitution of cross linkages in elastin. Nature, v.197, p.1297-8, 1963

PARTRIDGE, S.M.; ELSDEN, D.F.; THOMAS, J.; DORFMAN, A.; TELSER, A.; HO, P. Nature, v.209, p.399-400,1966.

PIERCE, R. A.; DEAK, S. B.; STOLLE, C. A.; BOYD, C. D. Heterogeneity of rat troelastin mRNA revealed by cDNA cloning. Biochem., v.29, p.9677-83, 1990.

PIERCE, R. A.; KOLODZIEJ, M. E.; PARKS, W. C. 1,25-dihydroxyvitamin D3 represses tropoelastin by a posttranscriptional mechanism. J. Biol. Chem., v.267, p.11593-99, 1992.

QUINTAS, M. L.; RODRIGUES, C. J.; YOO, J. H.; RODRIGUES JR, A. J. Age related changes in the elastic fibre system of the interfoveolar ligament. Rev. Hosp. Clin. Fac. Med. São Paulo, v.55, p.83-6, 2000.

ROBB, B. W.; WACHI, H.; SCAUB, T.; MECHAN, R. P.; DAVIS, E. C. Characterization on an in vitro model of elastic fiber assembly. J. Mol. Cell., v.11, p.3595-605, 1999. 
ROBINS, S. P.; SHIMOKOMASI, M.; BAILEY, A. J. The chemistry of the cross-links. Age-related changes in the reducible components of intact bovine collagen fibres. Biochem. J., v.131, p. 771-80, 1973.

RODRIGUES JR., A. J. Estudo morfofuncional do sistema de fibras elásticas da fáscia transversal na região inguinal no homem em várias idades. São Paulo, 1987. 75p. Tese (Livre Docência) - Faculdade de Medicina, Universidade de São Paulo.

RODRIGUES JR., A. J.; CASTRO DE TOLOSA, E. M.; FERRAZ DE CARVALHO, C. A. Electronic microscopy study on the elastic and elastic related fibers in the human fascia transversalis at different ages. Gegenbaurs. Morphol. Jahrb., v.136, p.645-52,1990.

RODRIGUES, C. J. Influencia do envelhecimento sobre o músculo diafragma: estudo das fibras musculares do sistema de fibras elásticas e do colágeno em ratos Wistar. São Paulo, 1994. 126p. Tese (Doutorado) - Faculdade de Medicina, Universidade de São Paulo, SP.

RODRIGUES, C. J.; RODRIGUES JR., A. J.; BOHM, G. M. The effects of ageing on the muscle fibers and collagen content of the diaphragm: $A$ comparison with the rectus abdominis muscle. Gerontol., v.42, p.218-28, 1996. 
RODRIGUES, C. J.; RODRIGUES JR., A. J. A comparative study of ageing of the elastic fibers system of the diaphragm and the rectus abdominis muscles in rats. Braz. J. Reser. Biol. Med., v.33, p.1449-54, 2000.

ROMERO, R.; KUIVANIEMI, H.; TROMP, G.; OLSON, J. M. The design, execution, and interpretation of genetic association studies to decipher complex diseases. Am. J. Obstet. Gynecol., v.187, p.1299-312.

ROSENBLOOM, J. Biology of Disease. Elastin: Relation of Protein and Gene Structure to Disease. Laboratory Investigation, v.51, p.605-23. 1984.

ROSS, R.; BORNSTEIN, P. The elastic fiber. The separation and partial characterization of its macromolecular components. J. Cell. Biol., v.40, p.366-81 1969 .

ROSS, R.; FIALKOW, P.; ALTMAN, .K. The morphogenesis of elastic fibers. Adv. Exp. Med. Biol., v.79, p.7-17,1977.

RYAN, P. Changing concepts in diverticular disease. Diseases of the Colon and Rectum, v.26, p.12-8, 1983.

SANDBERG, L. B.; WEISSMAN, N.; SMITH, D. W. The purification and partial characterization of a soluble elastin-like protein from copper-deficient porcine aorta. Biochem., V.8, p.2940-45, 1989. 
SANDBERG, L. B.; SOSKEL, N. T.; LESLIE, J. G. Elastin structure, biosynthesis, and relation to disease states. N. Engl. J. Med., v.304, p.56679, 1981.

SARDI. A.; GOKL, A.; SINGER, A. Diverticular disease of the cecum and ascending colon: a review of 881 cases. Am. Surg., v.53, p. 41-5, 1987.

SAYER, T. R.; DIXON, J. S.; HOSKER, G. L.; WARRELL, D. W. A study of paraurethral connective tissue in women with stress incontinence of urine. Neurourol. Urodynam., v.9, p.319-20, 1990.

SCHOETZ JR., D. J. Uncomplicated diverticulitis, indications for surgery and surgical management. Surg. Clin. North Am., v.73, p.965-93, 1993.

SCHOETZ JR., D. J. Diverticular disease of the colon: a century-old problem. Dis. Col. Rectum, v.42, p.703-9, 1999.

SEGAL, I.; SOLOMON, A.; HUNT, J. Emergence of diverticular disease in the urban South African black. Gastroenterol., v.72, p.755-9, 1977.

SIMPSON, J.; SCHOLEFELD, J. H.; SPILLER, R. C. Pathogenesis of colonic diverticula. Br. J. Surg., vol. 89, p.546-554, 2002. 
SLACK, W. W. Diverticular of the colon and their relation to the muscle layers and blood vessels. Gastroenterol., v.39, p.708-11, 1960.

SMITH, A. N.; SHEPHERD, J. The strength of the colon wall in diverticular disease. Br. J. Surg., v.63, p.666, 1976.

SMITH, A. N. Colonic Muscle in Diverticular Disease. Clin. Gastroenterol., v.15, p. 917,35, 1986.

SMITH, A. N.; SHEPHERD, J.; EASTWOOD, M. A. Pressure changes after balloon distension of the colon wall in diverticular disease. Gut, v.22, p.841$4,1981$.

SPRIGGS, E. I.; MARXER, O. A. Intestinal diverticula. Quarterly J. Med., v.19, p.1-34, 1925

SRIVASTVA, G. S.; SMITH, A. N.; PAINTER, N. S. Sterculia bulk-forming agent with smooth-muscle relaxant versus bran in diverticular disease. $\mathbf{B r}$. Med. J., v.1(6005) , p.315-8, 1976.

STEMMERMANN, G.; YANANI, R. Diverticulosis and polyps of the large intestine: a necropsy study of Hawaii Japanese. Cancer, v.31, p.1260-70, 1973. 
SUGIHARA, K. Diverticular disease of the colon in Japan. Ann. Acad. Med., v.16, p.504-8, 1987.

TANNURI, U.; RODRIGUES, C. J.; MAKSOUD FILHO, J.G.; SANTOS, M.; TANNURI, A. C.; RODRIGUES Jr., A. J. Effects of prenatal intra amniotic surfactant or dexamethasone administration on lung development are comparable to changes induced by tracheal ligation in an animal model of congenital diaphragmatic hernia. Study of lung glycogen content, elastic fiber density and collagen content. J. Pediat. Surg., v.33, n.12, p.1776-83, 1998.

TASSABEHJI, M.; METCALFE, K.; DONNAL, D.; HURST, J.; REARDON, W.; BRUCH, M.; READ, A. P. Elastin: genomic structure and point mutations in patients with supravalvular aortic stenosis. Hum. Mol. Gen., v.6, p.102936, 1997.

TASSABEHJI, M.; METCALFE, K.; HURST, J. et al. An elastin gene mutation producing abnormal tropoelastin and abnormal elastic fibers in a patient with autossomal dominant cutis laxa. Hum. Mol. Genet., v.7, p.1021-8, 1998.

TERRUZZI, V.; MINOLI, G.; FRIGERIO, G.; MARTINELLI, A.; CELESTE, B. Patologia colica associata alle diverticulosi del colon discendente e delsigma. Minn. Med., v.74, p.2301-4, 1983. 
THOMPSON, W. G.; PATEL, D. G. Clinical picture of diverticular disease of the colon. Clin. Gastroenterol., v. 15, p.903-16, 1986.

THOMSON, H. J.; BUSUTTIL, A.; EASTWOOD, M. A. The submucosa of the human colon. J. Ultrast. Mol. Struc. Research, v.96, p.22-30,1986.

THOMSON, H. J.; BUSUTTIL, A.; EASTWOOD, M. A.; SMITH, A. N.; ELTON, R. A. Submucosal collagen changes in the normal colon and in diverticular disease. Int. J. Colorect. Dis., v.2, p.208-13,1987.

TINOZZI, S.; BIANCHI, C.; TADDE, A.; BELISOMO, M.; VOLPATO, G.; MASSERA, F.; SILVESTRI, M. Epidemiologia e fisiopatologia delia malattia diverticolare del colon. Min. Chir., v.47, S, p.269-71, 1992.

UITTO, J. Elastic fibre abnormalities in skin disorders: what's new ? J. Acad. Dermatol. Vener., v.15, p.303-304, 2001.

ULMSTEN, U.; EKMAN, G.; GIERTZ, G.; MALMSTRÖN, A. Different biochemical composition of connective tissue in continent and stress incontinent women. Acta Obstet. Gynecol. Scand., v.66, p.455-7, 1987.

VERHOEFF, F. H. Some new staining methods of wide applicability including a rapid differential stain for elastic tissue. JAMA, v.50, p.876-7, 1908. 
VRHOVSKI, B.; WEISS, A. S. Biochemistry of tropoelastin. Eur. J. Biochem., v.259, p.1-18, 1998.

WAINWRIGHT, S. A.; BIGGS, W. D.; CURREY, J. D.; GOSLINE, J. M. Mechanical Design in Organisms. London: Edward Arnold, 1986.

WAGNER, D. E.; ZOLLINGER, R. W. Diverticulitis of the cecum and ascending colon. Areb. Surg., v.83, p.124-31, 1961.

WALDRON, D. J.; GILL, R. C; BOWES, K. L. Pressure response of human colon to intraluminal distension: comparison of the features of the African and European in vitro. Digest. Dis. Scien., v.34, p.1163-67. 1989.

WATTERS, D. A. K.; SMITH, A. N.; EASTWOOD, M. A.; ANDERSON, K. C.; ELTON, R. A.; MUGERWA, J. W. Mechanical properties of the colon; comparison of features of the African and European colon in vitro. Gut, v.26, p.384-92, 1985.

WEIGERT, C. Über cine methode zür faerbung elästischer fasern. Zbl. Aleq. Patb. Anat., v.9, p.289-92, 1898.

WEINREICH, J.; ANDERSON, D. Intraluminal pressure in the sigmoid colon. Scand. J. Gastroenterol., v.11, p.5 81-6, 1976. 
WESS, L.; EASTWOOD, M. A.; WESS, T. J.; BUSSUTIL, A.; MILLER, A. Cross linking of collagen is increased in colonic diverticulosis. Gut, v.37, p.91-4,1995.

WESS, L.; EASTWOOD, M. A.; EDWARDS, C. A.; BUSSUTIL, A.; MILLER, A. Collagen alteration in an animal model. Gut, v.38, p.701-6, 1996.

WESS, L.; EASTWOOD, M. A.; BUSSUTIL, A.; EDWARDS, C. A.; MILLER, A. An a association between maternal diet and colonic diverticulosis in animal model. Gut, v.39, p.423-7. 1996.

WHITEWAY, J.; MORSON, B. C. Elastosis in diverticular disease of the sigmoid colon. Gut, v.26, p.258-66, $1985 a$.

WHITEWAY, J.; MORSON, B.C. Pathology of the ageing: diverticular disease. Clin. Gastroenterol., v.14, p.829-46,1985b.

YAMAMOTO, M.; AOYAGI, M.; YAMAMOTO, K.; TAJIMA, S.; WACHI, H.; FUKAI, N.; MATSUSHIMA, Y. Increase in elastin gene expression and protein synthesis i arterial smooth muscle cells derived from patients with Moyamoya disease. Stroke, v.28, p.1733-38, 1997. 
YANAGISAWA, H.; DAVIS, E. C.; STARCHER, B. C,; OUCHI, T.; YANAGISAWA, M.; RICHARDSON, J. A.; OLSON, E. N. Fibulin-5 is an elastin-binding protein essential for elastic fiber development in vivo. Nature, v.415, p.168-71, 2002.

YOO, J. H. Alterações do gene da elastina nos pacientes portadores de hérnia inguinal. São Paulo, 2003. 80p. Tese (Doutorado) - Faculdade de Medicina, Universidade de São Paulo.

ZHANG, M. C.; HE, L.; GIRO, M. G., YONG, S.L.; TILLER, G. E.; DAVIDSON, J. M. Cuits laxa arising from frameshift mutations in exon 30 of the elastin gene. J. Biol. Chem., v.8, p.981-6, 1999. 